ANDIRA MICHELE DA CRUZ FICKINGER

PAPEL DOS RECEPTORES DE GLUTAMATO TIPO NMDA EM MACRÓFAGOS, CÉLULAS DENDRÍTICAS E CÉLULAS T CD4 ATIVADOS IN VITRO

Dissertação apresentada ao Programa de Pós-Graduação em Imunologia do Instituto de Ciências Biomédicas da Universidade de São Paulo, para obtenção do Título de Mestre em Ciências. 
ANDIRA MICHELE DA CRUZ FICKINGER

\section{PAPEL DOS RECEPTORES DE GLUTAMATO TIPO NMDA EM MACRÓFAGOS, CÉLULAS DENDRÍTICAS E CÉLULAS T CD4 ATIVADOS IN VITRO}

Dissertação apresentada ao Programa de Pós-Graduação em Imunologia do Instituto de Ciências Biomédicas da Universidade de São Paulo, para obtenção do Título de Mestre em Ciências.

Área de concentração: Imunologia

Orientador: Jean Pierre Schatzmann Peron

Versão corrigida. A versão original eletrônica encontra-se disponível tanto na Biblioteca do ICB quanto na Biblioteca Digital de Teses e Dissertações da USP (BDTD). 


\section{DADOS DE CATALOGAÇÃO NA PUBLICAÇÃO (CIP)}

Serviço de Biblioteca e Informaçăo Biomédica do Instituto de Ciências Biomédicas da Universidade de São Paulo

(9) reproduçăo total

Fickinger, Andira Michele da Cruz.

Papel dos Receptores de Glutamato tipo NMDA em macrófagos, células dendríticas e linfócitos T CD4+ ativados in vitro / Andira Michele da Cruz Fickinger. -- São Paulo, 2013.

Orientador: Prof. Dr. Jean Pierre Schatzmann Peron.

Dissertação (Mestrado) - Universidade de São Paulo. Instituto de Ciências Biomédicas. Departamento de Imunologia. Área de concentração: Imunologia. Linha de pesquisa: Neuroimunologia.

Versão do titulo para o inglês: The role of NMDA Glutamate Receptors in macrophages, dendritic cells and T CD4+ lymphocytes activated in vitro.

$\begin{array}{lll}\text { 1. Imunologia 2. Receptores de Glutamato 3. Glutamatos } & \end{array}$

4. Linfócitos T 5. Neurotransmissores I. Peron, Prof. Dr. Jean Pierre

Schatzmann II. Universidade de São Paulo. Instituto de Ciências

Biomédicas. Programa de Pós-Graduação em Imunologia III. Título. 
UNIVERSIDADE DE SÃO PAULO

INSTITUTO DE CIÊNCIAS BIOMÉDICAS

Candidato(a):

Título da Dissertação:

Orientador(a):
Andira Michele da Cruz Fickinger.

Papel dos Receptores de Glutamato tipo NMDA em macrófagos, células dendríticas e linfócitos T CD4+ ativados in vitro.

Prof. Dr. Jean Pierre Schatzmann Peron.

A Comissão Julgadora dos trabalhos de Defesa da Dissertação de Mestrado, em sessão pública realizada a . .1. ......... considerou
( ) Aprovado(a)
( ) Reprovado(a)

Examinador(a): $\quad$ Assinatura:

Nome:

Instituição:

Examinador(a): Assinatura:

Nome:

Instituição:

Presidente: Assinatura:

Nome:

Instituição: 


\section{Certificado}

Certificamos que o protocolo registrado sob $n^{\circ} \mathbf{1 7 4}$ nas fls. 114 do livro $\mathbf{0 2}$ para uso de animais em experimentação, sob a responsabilidade do Prof(a) $\operatorname{Dr}(a)$ ) Jean Pierre Schatzmann Peron, Coordenador (a) da Linha de pesquisa "Papel dos Receptores de Glutamato tipo NMDA em Macrófagos Células Dendríticas e Linfócitos T CD\$+" do qual participam o(s) aluno(s) Andira Michele da Cruz Fickinger, Wesley Nogueira Brandão e o pesquisador Niels Olsen Saraiva Câmara, está de acordo com os Princípios Éticos de Experimentação Animal adotado pela Sociedade Brasileira de Ciência de Animais de Laboratório (SBCAL) e foi aprovado pela COMISSÃO DE ÉTICA NO USO DE ANIMAIS (CEUA) em 16.02.2012, com validade de 4 anos.

São Paulo, 16 de fevereiro de 2012.

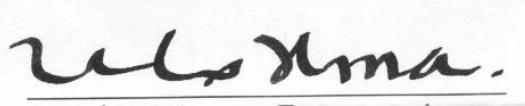

Prof.Dr.WOTHAN TAVARES DE LIMA

Coordenador

CEUA - ICB/USP

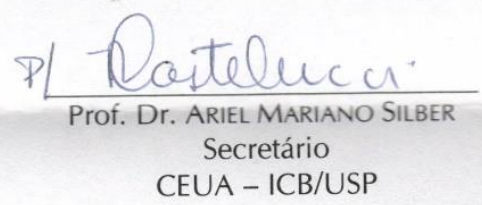


Aos meus pais, Amélia e René; às minhas irmãs, Amanda e Marie; aos meus sobrinhos, Frédéric e Isabelle. Com amor e carinho a vocês, que me encorajaram, me apoiaram e me aguentaram, mesmo nos momentos mais difíceis. 


\section{AGRADECIMENTOS}

Em primeiro lugar, gostaria de agradecer ao meu orientador, Jean Pierre, por me aceitar como aluna de Mestrado. Agradeço por toda as instruções, a ajuda, e a paciência ao longo de todo o projeto. Te admiro muito e aprendi muito com você.

Ao Wesley, meu querido companheiro de laboratório, que me ajudou inúmeras vezes e com o qual eu sempre pude contar. Não dá para imaginar o meu mestrado sem essa pessoa de bom-humor inacreditável, paciente, humilde, dedicado e prudente.

Agradeço ao Niels Olsen por permitir que meus experimentos fossem realizados em seu laboratório. Agradeço também por ter tido a oportunidade de, no tempo em que convivi em seu laboratório, conhecer essa pessoa única, humilde, sincera e inteligente que ele é.

À Eni, que me ajudou demais durante todo o meu tempo de mestrado. Devo muito a essa mulher.

Aos meus colegas de laboratório, Verônica, Cristiano e Juliana. Trabalhar com pessoas como vocês torna a difícil rotina de laboratório menos difícil e até mesmo prazerosa. Obrigada pelos momentos de descontração, de conversas construtivas (...ou não) e pelo ombro amigo nos momentos difíceis.

À minha querida amiga Ana Carolina Durão, colega "postiça" de laboratório, uma pessoa muito querida, animada e inteligente, e que me mostrou algumas vezes que as coisas podem ser mais simples do que eu imagino.

Aos alunos do Laboratório de Imunologia de Transplantes do Professor Dr. Niels Olsen, Daniel, Ângela, Mariane, Matheus, Tárcio, Andrea Caricilli, Vinícius, Ênio, Felipe, Danilo, Marina, Cristiane, Raphael. Obrigada por me ensinarem, por me ajudarem em momentos de dúvida e pela amizade. Tenho por todos um carinho muito especial.

À Carla Sá, ex-aluna do Laboratório de Imunologia dos Transplantes. Sou muito agradecida por ter tido a oportunidade de ter conhecido essa garota tão inteligente, carinhosa, engraçada e honesta. Uma amigona que faz muita falta.

À Meire por me ajudar e socorrer tantas vezes, pelas orientações, pelas conversas e pelo carinho. Muito obrigada mesmo, por tudo que você fez por mim.

Ao pessoal do Laboratório de Neuroendocrinofarmacologia e Imunomodulação da Professora Dra. Carolina Munhoz, em especial ao Nilton, pela grande ajuda em técnicas experimentais. 
A todo o pessoal do Laboratório do Professor Dr. João Gustavo Pessini Amarantes Mendes e e garotas da Professora Dra. Jaqueline Jacysyn, Nathália, Paola e Carol. Agradeço por toda a ajuda e a amizade de vocês.

Aos funcionários do Departamento de Imunologia. Ao Milton e Otacílio que sempre me trataram com muito carinho; ao Israel sempre tão solícito e que tanto me ajudou com meus difíceis camundongos; ao Moisés, sempre muito prestativo; à Silvia Massironi, Ana Tada e Márcio, pelo auxílio e orientações quanto aos cuidados com animais; e logicamente à Dona Áurea, sempre tão gentil e acolhedora. 
"A escolha é possível, em certo sentido, porém o que não é possível é não escolher. Eu posso sempre escolher, mas devo estar ciente de que, se não escolher, assim mesmo estarei escolhendo. Contudo, viver é isso: Ficar se equilibrando o tempo todo, entre escolhas e consequências." 


\section{RESUMO}

Fickinger AMF. Papel dos Receptores de Glutamato tipo NMDA em linfócitos T ativados in vitro. [dissertação (Mestrado em Imunologia)]. São Paulo: Instituto de Ciências Biomédicas, Universidade de São Paulo; 2013.

A neuroimunologia é o ramo da imunologia que estuda a relação entre sistema imune e o sistema nervoso. Muitos estudos têm demonstrado a capacidade direta de neurotransmissores em modular a resposta imune, assim como de citocinas em influenciar funções cognitivas. Neste contexto, o glutamato possui papel de destaque, por se tratar do neurotransmissor excitatório mais importante e mais abundante no sistema nervoso central dos mamíferos. Sua função é exercida por dois tipos de receptores principais: i) os receptores ionotrópicos (iGluR) e ii) os receptores metabotrópicos (mGluR). A descoberta da expressão de receptores de glutamato em células do sistema imune tem despertado interesse científico, levantando questões acerca de sua expressão e função. No presente trabalho, avaliamos parâmetros como viabilidade celular, linfoproliferação e ativação de MAP quinase pelo receptor NMDAR esplenócitos totais e linfócitos cultivados in vitro. Nossos resultados demonstram que linfócitos em repouso e ativados apresentam diferentes perfis de expressão do receptor NMDAR. O uso do antagonista deste receptor, o MK801, foi capaz de reduzir a proliferação de linfócitos T CD4 e T CD8 estimulados com anti-CD3 em cultura de esplenócitos. Tal redução pode ser explicada por um aumento na taxa de morte celular, o que foi avaliado por marcação com anexina- $\mathrm{V}$, indicador de apoptose, ou 7-AAD, indicador de necrose. Para entendermos um pouco a respeito da sinalização do receptor NMDAR no sistema imune, avaliamos a fosforilação da MAP quinase ERK 1,2 em linfócitos T CD4 ativados na presença do agonista (NMDA) ou do antagonista (MK801) do receptor. Observamos um aumento na ativação desta quinase na presença de NMDA, o que é revertido na presença do MK801. Ao avaliar o papel do receptor NMDAR in vivo, verificamos uma redução significativa na gravidade da encefalomielite experimental autoimune em animais tratados com MK801. Mais interessante, esta redução se correlaciona também com uma redução na fosforilação de ERK 1,2 em esplenócitos totais obtidos ao dia 7 pós-imunização. Em resumo, nossos dados sugerem que o receptor NMDA possui o papel de ativador de vias intracelulares importantes, como as da MAP quinase ERK 1,2; e que o seu bloqueio resulta em morte celular in vitro. Logo, isso indica a importância do glutamato como modulador da intensidade da resposta e viabilidade de linfócitos T CD4 e T CD8 in vitro e in vivo. Sendo assim, nossos resultados contribuem para um melhor entendimento dos fenômenos de imunoregulação, especialmente aqueles no campo da neuroimunologia ou neuroimunomodulação.

Palavras-chave: NMDAR. Glutamato. Receptores ionotrópicos de glutamato. Neurotransmissores. Neuroimunomodulação. Linfócitos. T CD4. 


\begin{abstract}
Fickinger AMF. The role of NMDA Glutamate Receptors in T lymphocytes activated in vitro. [Dissertation (Master thesis in Immunology)]. São Paulo: Instituto de Ciências Biomédicas, Universidade de São Paulo; 2013.

Neuroimmunology is a field within immunology which studies the relationship between the nervous system and the immune system. Several studies have demonstrated the direct ability of neurotransmitters in modulating the immune response, as for cytokines in influencing cognitive functions. In this context, glutamate stands out for being the most important and abundant neurotransmitter in the mammal central nervous system. Its role is exerted through two main types of receptor: i) ionotropic receptors (iGluR) and ii) metabotropic receptors (mGluR). The discovery of glutamate receptor expression in immune cells has led to scientific interest, raising issues concerning its expression and function. In the present study, we evaluated parameters such as cell viability, lymphoproliferation, and activation of the MAP quinase pathway by the NMDA receptor on total splenocytes and lymphocytes cultured in vitro. Our results demonstrate that naive and activated lymphocytes present different profiles of NMDA receptor expression. The use of MK801, an antagonist for this receptor, was able to reduce the T CD4 and T CD8 lymphocyte proliferation stimulated with anti-CD3 in splenocyte culture. Such reduction may be explained by the increase of the cellular death rate, evaluated by annexin-V staining, indicator of apoptosis or 7-AAD, indicator of necrosis. With the intent of understanding part of the NMDA receptor signaling in the immune system, we evaluated the ERK 1,2 MAP quinase phosphorylation in T CD4 lymphocytes activated in the presence of the agonist (NMDA) or the antagonist (MK801) of the receptor. We observed an increase in this quinase activation in the presence of NMDA, which is reversed by the MK801. When evaluating the role of the NMDA receptor in vivo, we verified a significant reduction in the degree of experimental auto-immune encephalomyelitis in animals treated with MK801. More interesting, this reduction also correlates to a reduction on the phosphorilation of ERK 1,2 in total splenocytes obtained at the seventh day post-immunization. In sum, our data suggest that the NMDA receptor has the role of activating important intracellular pathways, such as the MAP quinases ERK 1,2; and that its blockage results in cellular death in vitro. As so, this indicates the importance of glutamate as a modulator of the intensity of response and the viability of T CD4 e T CD8 lymphocytes in vitro e in vivo. Thus, our result contribute for a better understanding of the immunoregulation phenomena, especially those in the neuroimmunology ou neuroimmunomodulation field.
\end{abstract}

Keywords: NMDAR. Glutamate. Ionotropic Glutamate Receptors. Neurotransmitters. Neuroimmunomodulation. Lymphocytes. T CD4. 


\section{LISTA DE FIGURAS}

Figura 1: Esquema ilustrativo do receptor NMDAR

Figura 2: Vias de sinalização do NMDAR

Figura 3: Expressão da subunidade NR1 do receptor NMDAR em linfócitos

T CD4 murinos 32

Figura 4: Expressão dos genes para IL-2, IL-10, RORc e SOCS-3 em células DO 11.10 ativadas in vitro

Figura 5: Ativação da via de sinalização das MAP Quinases ERK-1

e ERK-2 pelo NMDAR

Figura 6: Linfoproliferação de Linfócitos T CD4 e CD8 em culturas

de esplenócitos totais 36

Figura 7: Linfoproliferação de Linfócitos T CD8 em culturas de esplenócitos totais

Figura 8: Bloqueio do NMDAR induz Apoptose em Linfócitos T CD4

e CD8 em culturas de esplenócitos totais 37

Figura 9: Bloqueio de receptor NMDAR induz apoptose em linfócitos totais 38

Figura 10: Bloqueio de receptor NMDAR produz redução na viabilidade celular de esplenócitos totais 39

Figura 11: Bloqueio de NMDAR produz redução na gravidade de EAE in vivo 40

Figura 12: Bloqueio do NMDAR in vivo reduz a fosforilação de MAP Quinases ERK-1 e ERK-2 em esplenócitos totais 


\section{LISTA DE ABREVIATURAS E SIGLAS}

5-HTR: $\quad$ 5-Hydroxytriptamine Receptor

7-AAD: 7-Aminoactinomycin D

ACTH: $\quad$ Adrenocorticotropic Hormone

AKT: nome derivado do primeiro vírus akt clonado a partir de uma translocação no alelo dessa proteína

AMPA: $\quad \alpha$-Amino-3-Hydroxy-5-Metil-4-Isoxazolepropionic Acid

AMPc: $\quad$ Cyclic Adenosin Mono Phosphate

AP-1: $\quad$ Activator Protein-1

AP-5: $\quad$ Activator Protein-5

AP5: 2-Amino-5-Phosphonovalerate

AVC: $\quad$ Acidente Vascular Cerebral

$\beta$-1AR: $\quad$ beta-1 Adrenergic Receptor

B-2AR: $\quad$ beta-2 Adrenergic Receptor

BDNF: Brain-Derived Neurotrophic Factor

$\mathrm{Ca}^{++}$: $\quad$ Cálcio

CAMIIK: Calmodulin Quinase II

cDNA: $\quad$ Codifying DNA

CFA: $\quad$ Complete Freund Adjuvant

D1: $\quad$ Dopamine Receptor 1

D5: $\quad$ Dopamine Receptor 5

DAG: Diacylglycerol

DAPI: 4,6-Diamidino-2-Phenylindole

dATP: Deoxyadenosine Triphosphate

dCTP: Deoxycytidine Triphosphate

dGTP: Deoxyguanosine Triphosphate

dNTP: Deoxyribonucleotide Triphosphate

DTT: Dithiothreitol

dTTP: Deoxythymidine Triphosphate

EAAT: Excitatory Aminoacid Transporter

EAE: Experimental Autoimmune Encephalomyelitis

ERK: $\quad$ Extracellular Signal-Regulated Kinase

GLAST: Glial Glutamate and Aspartate Transporter

GLT: Glial Glutamate Transporter

GltT: $\quad$ L-Glutamate Transporter

GSK-3 $\quad$ Glycogen Synthase Kinase-3

ICV: Intracranioventricular

IFN $\gamma$ : Interferon gamma

IL-1 $\beta$ : Interferon 1 beta

IL-2: $\quad$ Interleucina 2

IL-6: $\quad$ Interleucina 6

IL-10: $\quad$ Interleucina 10

iNOS: Inducible Nitric Oxide Synthase

$\mathrm{IP}_{3}$ : $\quad$ Inositol Triphosphate 


$\begin{array}{ll}\text { JNK: } & \text { C-Jun N-Terminal Kinases } \\ \text { K+: } & \text { Potássio } \\ \text { LFA-1: } & \text { Leucocyte Function Associated Antigen-1 } \\ \text { LPS: } & \text { Lipopolysaccharide } \\ \text { MAP: } & \text { Mitogen Activated Protein } \\ \text { mGluR: } & \text { Metabotropic Glutamate Receptor } \\ \text { MOG: } & \text { Myelin Oligodendrocyte Glycoprotein } \\ \text { MK801: } & \text { 5-Methyl-10,11-Dihydro-5H-Dibenzo[a,d]Cyclohepten-5,10-Imine } \\ \text { Na': } & \text { Sódio } \\ \text { NF-AT: } & \text { Nuclear Factor of Activated T Cells } \\ \text { NFkB: } & \text { Nuclear Factor kappa Light Chain Enhancer of Activated B Cells } \\ \text { NMDA: } & \text { N-Methyl-D-Aspartate } \\ \text { NR1: } & \text { NMDA Receptor Subunit 1 } \\ \text { NR2B: } & \text { NMDA Receptor Subunit 2B } \\ \text { OVA: } & \text { Ovalbumin } \\ \text { PCR: } & \text { Polimerase Chain Reaction } \\ \text { PLC: } & \text { Phospholipase C } \\ \text { RIPA: } & \text { Radioimmunoprecipitation Assay } \\ \text { RORc: } & \text { RAR Related Orphan Receptor C } \\ \text { RORyt: } & \text { RAR Related Orphan Receptor gamma T } \\ \text { ROS: } & \text { Reactive Oxygen Species } \\ \text { RPMI: } & \text { Roswell Park Memorial Institute medium } \\ \text { SFB: } & \text { Soro Fetal Bovino } \\ \text { SNAS: } & \text { Sistema Nervoso Autônomo Simpático } \\ \text { SNAT: } & \text { System N Astrocyte Transporter } \\ \text { SNC: } & \text { Sistema Nervoso Central } \\ \text { SNP: } & \text { Single Nucleotide Polymorphisms } \\ \text { SOCS-3: } & \text { Suppressor of Cytokine Signaling 3 } \\ \text { STAT: } & \text { Signal Transducer and Activator of Transcription } \\ \text { SYK: } & \text { Spleen Tirosine Kinase } \\ \text { TA: } & \text { Temperatura Ambiente } \\ \text { T CD4: } & \text { T Cell of Cluster Differentiation 4 } \\ \text { T CD8: } & \text { T Cell of Cluster Differentiation } 8 \\ \text { TCR: } & \text { T Cell Receptor } \\ \text { TEC: } & \text { Thymic Epithelial Cell } \\ \text { Th17: } & \text { T Helper 17 Cell } \\ \text { TNFa: } & \text { Tumor Necrosis Factor alpha } \\ \text { VGLUT: } & \text { Vesicular Glutamate Transporter } \\ & \end{array}$




\section{LISTA DE SÍMBOLOS}

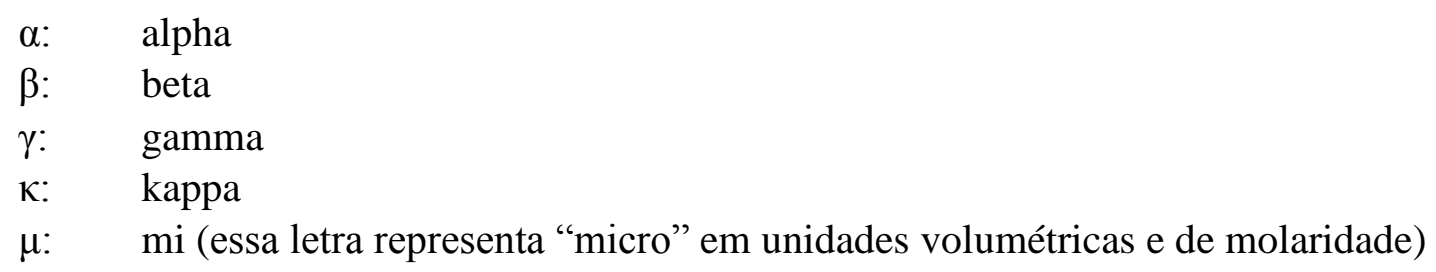




\section{SUMÁRIO}

1 INTRODUÇÃO

1.1 O Glutamato e sua biologia no Sistema Nervoso Central ……..................... 17

1.2 Os Receptores de Glutamato NMDAR e o Sistema Imune ....................................... 20

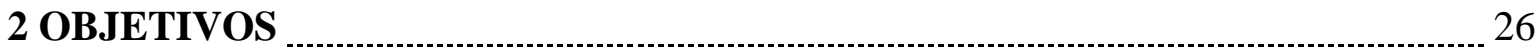

3 MATERIAIS E MÉTODOS 27

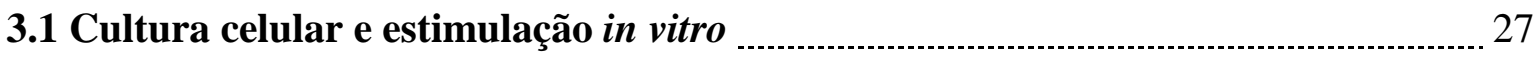

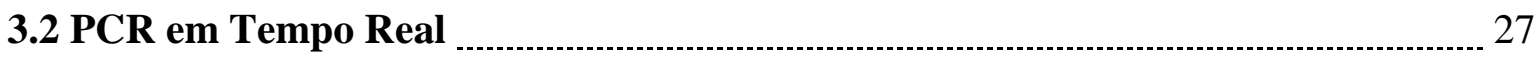

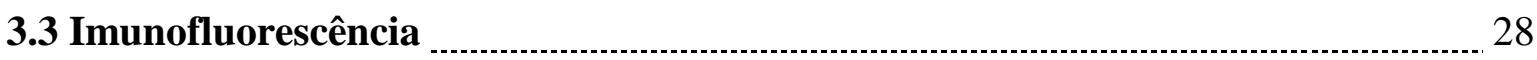

3.4 Western Blot

3.5 Imunização para Indução de EAE (Encefalomielite

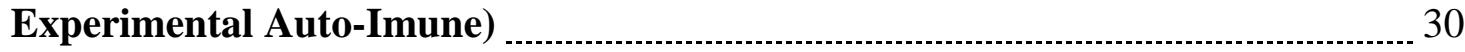

3.6 Citometria de Fluxo $\ldots \ldots \ldots \ldots \ldots \ldots$

3.7 Análise Estatística $\ldots \ldots \ldots \ldots$

4 RESULTADOS 32

4.1 Linfócitos T CD4 murinos expressam NMDAR _... 32

4.2 Estímulo por N-metil-D-Aspartato em células DO11.10

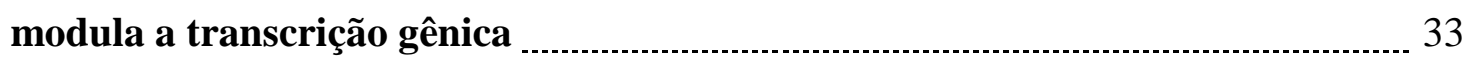

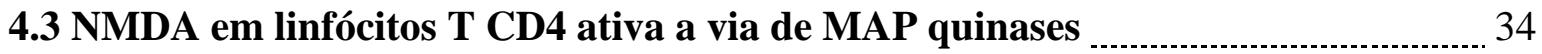

4.4 Bloqueio da ativação de NMDAR reduz a proliferação de linfócitos T CD4 e T CD8

4.5 Redução da linfoproliferação se dá às custas de aumento de apoptose ….............. 35

4.6 Tratamento com MK801 in vivo reduz a gravidade da encefalomielite experimental auto-imune

4.7 Tratamento com MK801 in vivo reduz a fosforilação de MAP quinase

ERK 1,2 em esplenócitos totais de animais com EAE ........................................... 41

5 DISCUSSÃO 42

6 CONCLUSÃO

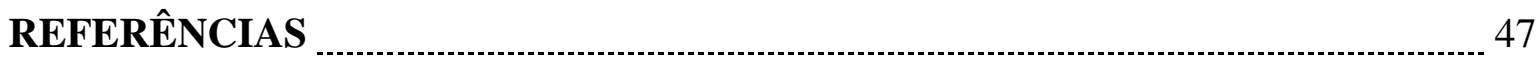




\section{INTRODUÇÃO}

A neuroimunomodulação é definida como "uma interação bidirecional complexa entre o sistema nervoso e o sistema imune, repercutindo em mudanças nas funções biológicas de um ou de ambos os sistemas" [1]. Sendo assim, estímulos ambientais ou fisiológicos que afetam um dos sistemas, invariavelmente acarretarão em alterações no outro. Uma grande parte dessas descobertas foi alcançada após a exposição de animais experimentais a situações de estresse, como sons altos, choques elétricos, exposição à luminosidade ou temperaturas extremas, rompimento de condições de co-habitação, alimentação, isolamento, etc [1]. De fato, já em 1936, Hans Selye cunhou o termo Síndrome Geral Adaptativa (do inglês: General Adaptive Syndrome), mais tarde por ele renomeada de resposta ao stress (do inglês; Stress Response) [2, 3]. Esta compõe um complexo quadro de alterações fisiológicas, mais tarde caracterizado como resultado da ativação do eixo chamado hipotálamo-hipófise-adrenal (HPA, por se referir a hipotálamo-pituitária-adrenal; pituitária é outro nome dado à hipófise), cuja principal molécula efetora é o glicocorticóide, um potente imunossupressor endógeno [4]. Um exemplo interessante da ativação deste eixo foi demonstrado em indivíduos submetidos ao salto de bungee jump. Os indivíduos apresentaram minutos após o salto um aumento abrupto nas concentrações de ACTH, noradrenalina e corticosteróides circulantes. A ação sistêmica desses hormônios resulta em uma redução de fatores importantes da imunidade inata e adaptativa, além de uma leucopenia transiente [5]. Vale ressaltar que estas alterações foram menos significantes em indivíduos previamente tratados com um antagonista dos receptores adrenérgico $\beta 1$ e $\beta 2$ ( $\beta 1$ Ar e $\beta 2$ Ar), o propranolol. Sendo assim, é inegável o fato de que o sistema nervoso e o sistema imune apresentam uma relação muito íntima, e alterações em um dos sistemas, afetará o outro como consequência $[1,6,7]$.

Não podemos negligenciar também a presença de terminações nervosas eferentes do sistema nervoso autônomo simpático (SNAS) nos órgãos linfóides, como medula óssea, timo, baço e linfonodos [7]. Tais inervações possibilitam interações diretas entre o sistema nervoso e seus neurotransmissores com os leucócitos residentes nestes órgãos, como demonstrado recentemente [8]. Além disso, demonstrou-se que animais tratados com LPS apresentaram um menor aumento nos níveis séricos de TNF- $\alpha$ quando comparados a animais vagotomizados. Tal fenômeno foi chamado de resposta anti-inflamatória colinérgica (do inglês; Antiinflammatory Cholinergic Response) [9]. 
Mais recentemente, o mesmo grupo demonstrou que tal fenômeno é mediado pela ativação vagal de ramos do nervo esplênico pois, mediante a a secreção de noradrenalina, ocorre a indução da secreção de acetil-colina por linfócitos T CD4. Sendo assim, o grupo descreve uma população de células T CD4 esplênicas colina acetil-transferase positiva [8]. Tais descobertas possibilitam o estabelecimento de novos conceitos em neuroimunologia ou neuroimunomodulação, não só acerca do controle homeostático do sistema imune, como também na vigência de várias doenças, sejam essas de natureza infecciosa, inflamatória ou autoimune.

Doenças neuroinflamatórias são aquelas cujo processo inflamatório se instala dentro do sistema nervoso central ou periférico $[10,11]$. Sendo assim, baseado no exposto acima, é plausível pensarmos que as células infiltrantes do SNC também sejam alvos da ação dos neurotransmissores ali presentes. Isso devido ao fato de que é cada vez mais frequente a descrição da presença de receptores para neurotransmissores em células do sistema imune, como receptores nicotínicos $\alpha 7$ [12], adrenérgicos $\beta 1$ AR e $\beta 2$ AR [13], serotoninérgicos 5-HTR [14], dopaminérgicos D1 e D5 [15, 16], glutamatérgicos NMDAR [17] e mGluR4 [18], entre muitos outros [19]. Logo, estudos com a finalidade de compreender a capacidade imunomoduladora dos neurotransmissores se mostram promissores, uma vez que podem fornecer pistas importantes para o tratamento de doenças neuroinflamatórias crônicas, como esclerose múltipla, esclerose lateral amiotrófica ou Doença de Alzheimer.

\subsection{O Glutamato e sua biologia no Sistema Nervoso Central}

Dentre as sinapses do SNC, 95\% das mesmas são do tipo glutamatérgicas, tornando o glutamato o principal neurotransmissor excitatório do SNC de mamíferos, como primeiramente descrito em 1954 [20, 21]. O glutamato possui um papel crucial na grande maioria das funções neuronais, atuando em processos de plasticidade, aprendizado, consolidação da memória e cognição [22]; além de atuar no desenvolvimento do sistema nervoso central pela indução e eliminação de sinapses, migração celular, diferenciação e morte de células neuronais [22].

Todavia, concentrações altas desse neurotransmissor fora da fenda sináptica podem induzir uma ativação excessiva destes receptores, com grande influxo de cálcio e posterior morte celular por apoptose, num processo conhecido por excitotoxicidade [23]. A fim de impedir o acúmulo excessivo deste neurotransmissor e assim suas funções deletérias, o SNC dispõe de sistemas complexos de recaptação e conversão do glutamato em componentes menos nocivos. Existem duas vias principais de conversão do glutamato: i) a conversão em glutamina 
pela enzima glutamina-sintetase, expressa principalmente em astrócitos; ii) e a conversão para $\alpha$-cetoglutarato, através da desaminação pela glutamato desidrogenase ou transaminação pela ação de transaminases [24-26]. A glutamina e o $\alpha$-cetoglutarato podem ser utilizados em processos metabólicos diversos ou transformados novamente em glutamato para ser re-utilizado como neurotransmissor [26]. Já os transportadores de glutamato possuem papel primordial na recaptação ou transporte intracelular, sendo os mais importantes: GLAST/EAAT1 (do inglês; Glial Glutamate and Aspartate Transporter; Excitatory Amino Acid Transporter), GLT/EAAT2 (do inglês; Glial Glutamate Transporter; Excitatory Amino Acid Transporter 2), o transportador bi-direcional SNAT3 (do inglês; System N Astrocyte Transporter) além do transportador vesicular VGLUT (do inglês: Vesicular Glutamate Transporter) [26].

A função biológica do glutamato é exercida pela ativação de duas famílias de receptores de membrana, chamados ionotrópicos e metabotrópicos, sendo os receptores ionotrópicos (iGluR) os primeiros a serem descobertos durante a década de 70 [21, 22, 26]. Os receptores ionotrópicos são denominados de acordo com seus agonistas principais: N-metil-D-aspartato (NMDA), 2a-amino-3-hidroxi-5-metil-4-ácido isoxazolepropoiônico (AMPA) ou kainato. Tais receptores são multímeros protéicos transmembrânicos arranjados na forma tetramérica ou pentamérica, sendo que todos apresentam permeabilidade seletiva para $\mathrm{Ca}^{++} \mathrm{e}^{+}$, variando de acordo com as subunidades presentes.

Na década de 1980, foi descoberta também a existência de receptores metabotrópicos de glutamato (mGluR), caracterizados pelo acoplamento à proteínas $\mathrm{G}$ de membrana e pela ação através da liberação de segundos mensageiros [27]. São também divididos em três grupos: grupo I (mGluR1 e mGluR5), grupo II (mGluR2 e mGluR3) e grupo III (mGluR4, mGluR6, mGluR7 e mGluR8) [27]. Os receptores dos grupos I e II são ativados por 1-aminociclopentano-trans-1,3-ácido dicarboxílico (trans-APCD), ao passo que receptores do grupo III são ativados por L-2-amino-4-ácido fosfobutírico (L-AP4). O grupo I está acoplado a fosfolipase C (PLC) e, portanto, está associado à produção de inositol trifosfato $\left(\mathrm{IP}_{3}\right)$ e diacilglicerol (DAG), ao passo que os grupos II e III são acoplados à proteína G inibitórias de adenilato ciclase, reduzindo os níveis de AMPc intracelular [27].

Nomeado após a descoberta de seu agonista mais potente, o $N$-metil-D-aspartato (NMDA), o NMDAR é um receptor ionotrópico de maior afinidade, envolvido em inúmeros processos fisiológicos (plasticidade sináptica, plasticidade neuronal, aprendizado, memória) e patológicos do SNC (excitotoxicidade, neurodegeneração), como mencionado acima [28]. Como exemplo, a infusão intracranioventricular (ICV) de antagonistas de NMDAR em ratos demonstrou que o bloqueio crônico desse receptor prejudica o aprendizado espacial. Após a 
publicação desses resultados, novos experimentos com animais deficientes para subunidades de NMDAR específicas do hipocampo corroboraram tais achados [29].

O NMDAR é um canal iônico tetramérico, geralmente composto de duas subunidades NR1 e duas subunidades do tipo NR2 (NR2A, NR2B, NR2C, NR2D ou NR2E). A subunidade NR1 possui oito isoformas distintas resultantes de splicing, sendo está presente em todos os subtipos de NMDAR. A subunidade recém-descoberta NR3 (NR3A e NR3B), quando expressa, é encontrada associada ao conjunto de NR1/NR2 [28, 30].

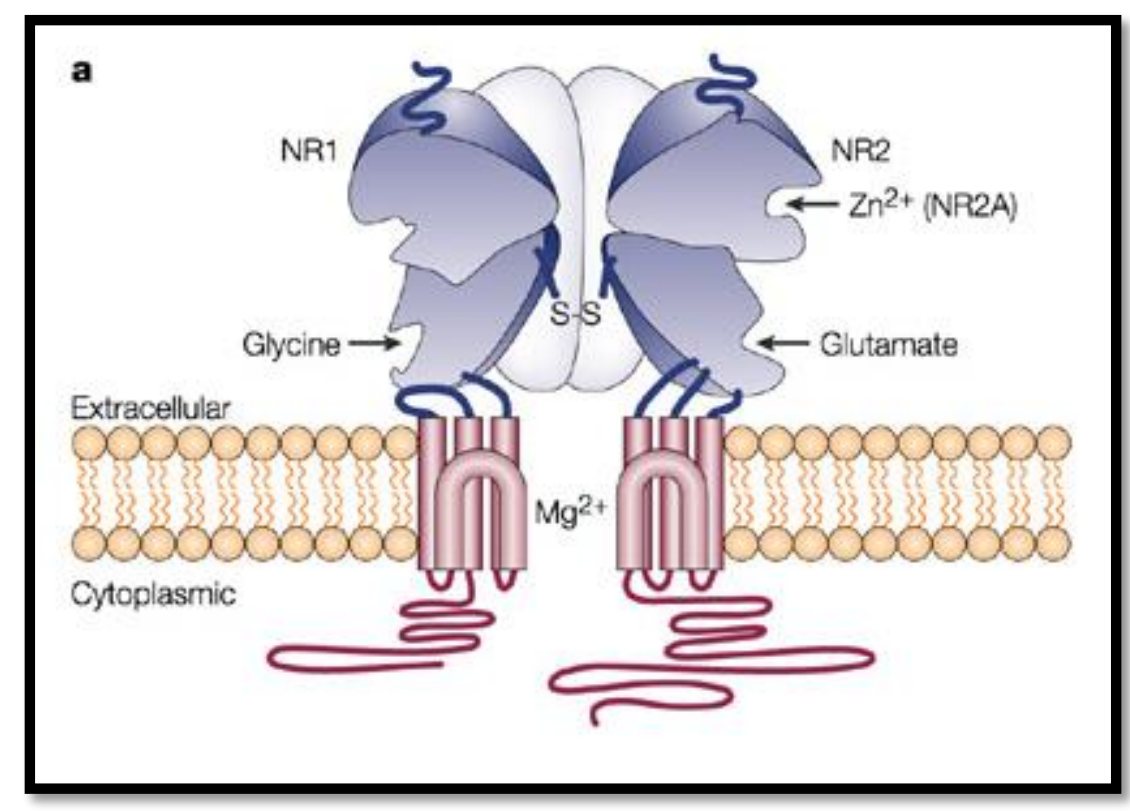

Figura 1 - Esquema ilustrativo do receptor NMDAR. A figura mostra sua estrutura transmembrana e seus sítios de ligação para glutamato e glicina. O receptor NMDAR é um canal iônico de cálcio, mas pode ser bloqueado por magnésio. Fonte: Witt A, Macdonald N, Kirkpatrick P. Memantine hydrochloride. (2004) Nature Reviews Drug Discovery 3, 109-110 [31].

Funcionalmente, os receptores do tipo NMDAR são voltagem-dependentes, resultando em influxo de $\mathrm{Ca}^{2+}$ e $\mathrm{Na}^{+}$e efluxo de $\mathrm{K}^{+}$. A ativação desses receptores depende da despolarização de membrana para o desacoplamento do magnésio e subsequente ligação de glicina à subunidade NR1 e glutamato à subunidade NR2 ou NR3. A posterior abertura do canal iônico ocorre por meio de alterações conformacionais.

Intracelularmente, os receptores NMDAR podem ser fosforilados por serina/treonina proteína quinase C (do inglês; Protein Quinase C), proteína quinase A (do inglês; Protein Quinase A), proteína quinase II Cálcio/Calmodulina-dependente (CaMKII), e tirosina quinases do tipo Src e Fyn. Tais fosforilações podem ser revertidas por serina e treonina fosfatases 1, 2A e 2B (calcineurina) e outras tirosina fosfatases endógenas [33].A inibição de proteínas tirosinas fosfatases endógenas resulta na potencialização da ação do NMDAR, indicando que essas modulam a funcionalidade deste receptor [27, 32]. 
De fato, diversos subtipos de NMDAR já foram identificados, e esses diferem quanto à sensibilidade a ligantes endógenos e exógenos, permeabilidade e bloqueio por íons divalentes, propriedades cinéticas e interação com proteínas intracelulares. Vários antagonistas, tanto competitivos como não competitivos têm sido desenvolvidos e usados nos estudos do NMDAR. Dentre estes podemos citar o antagonista competitivo AP-5 (D-2-amino-5-ácido fosfopentanóico), e os antagonistas não-competitivos dextrometorfano, pentazocina, ketamina, memantina, amantidina, e MK-801 [30, 33].

\subsection{Os Receptores de Glutamato NMDAR e o Sistema Imune}

Receptores de glutamato do tipo NMDAR já foram descritos em humanos e murinos também fora do SNC, como em células renais, pulmonares, esplênicas, testiculares, ovarianas, ósseas, pancreáticas e hematopoiéticas. Devemos citar o fato de que o NMDAR também é expresso na membrana mitocondrial, adicionando ainda mais complexidade à sua biologia [34]. Acredita-se que a expressão de receptores tipo NMDA em células imunocompetentes tem importante papel imunomodulador sobre as mesmas, apesar de que uma grande parte dessas informações serem apenas especulativas.

A expressão de receptores de glutamato também já observada em células do sistema imune. De fato, tanto células da resposta imune inata como adaptativa podem expressar algum tipo de receptor de glutamato, seja metabotrópico ou ionotrópico. Todavia ainda foi pouco explorado o potencial de tal receptor em células imunes, deixando um campo bastante rico a ser explorado e compreendido.

A expressão de NMDAR em neutrófilos ativados in vivo já foi demonstrada por métodos de imunofluorescência. Quando ativados na presença de $500 \mu \mathrm{M}$ de NMDA, os mesmos são capazes de aumentar a síntese de ROS (do inglês; Reactive Oxygen Species), que é revertida pela exposição ao MK-801. Infelizmente ainda há pouca compreensão dos mecanismos efetores da ativação do NMDAR em neutrófilos, mas especula-se que podem iniciar-se cascatas próapoptóticas ou anti-apoptóticas. Supõe-se também que cascatas pró-apoptóticas geradas pela ativação do receptor atuem de forma regulatória, eliminando neutrófilos hiperativos e potencialmente perigosos. De forma interessante, foi recentemente demonstrado que durante a meningite por Neisseria meningitidis, a bactéria capta glutamato livre por seu transportador GltT, e assim se evadindo da ação de espécies reativas do oxigênio produzidas pelos neutrófilos infiltrantes [35]. 
No timo, um órgão linfoide primário, acredita-se que o NMDAR esteja envolvido na maturação e geração de linfócitos T. Recentemente foi demonstrado que os timócitos expressam as subunidades NR1, NR2A e NR2B do receptor NMDA. Além disso, a interação TECs (do inglês; Thymic Epithelial Cells), uma rica fonte de glutamato, com os timócitos, é capaz de induzir um grande influxo de cálcio, fenômeno revertido pela adição dos antagonistas memantina e MK801. Mais interessante, foi demonstrado por microscopia confocal que o receptor tipo NMDA e o TCR (do inglês: T Cell Receptor) se colocalizam na sinapse imunológica após ativação por beads ou apresentação de antígeno [37]. Todavia, tal trabalho não avalia o papel funcional deste receptor, permitindo-nos somente supor os eventos celulares e moleculares mediados pelo glutamato durante a ontogenia de linfócitos T.

Em linfócitos T maduros, a expressão de NMDAR também já foi observada, tanto em humanos como em roedores, avaliado tanto através do mRNA para grin1 [20], como através da utilização de glutamato tritiado $\left(\mathrm{H}^{3}\right)$. Tais resultados mostraram uma interação estável com seu receptor, sendo desfeita somente com o uso de quisqualato, antagonista para receptores ionotrópicos. Todavia, o perfil de expressão dos receptores tipo NMDAR, ainda não é conhecido por completo, restando algumas perguntas importantes: i) quais subunidades são encontradas no sistema imune? ii) em quais populações celulares? iii) há diferenças entre células naive ou ativadas? Tais quebra-cabeças ainda devem ser desvendados.

Em relação à funcionalidade dos receptores de glutamato no sistema imune, apesar de escassos, e na sua maioria realizados in vitro, apresentaram resultados interessantes. Por exemplo, a incubação de linfócitos T com o agonista NMDA induz: i) superexpressão do próprio receptor NMDAR, ii) aumento da concentração de cálcio intracelular, iii) supressão da linfoproliferação em resposta a fitohemaglutinina e iii) alteração no perfil de citocinas [17]. Vale ressaltar que todos esses efeitos foram revertidos pela adição dos antagonistas específicos AP5 ou MK-801.

Além da importância do glutamato na modulação de células inflamatórias do SNC, o mesmo também pode exercer esse papel na periferia. Estudos recentes demonstraram que DCs esplênicas são capazes de secretar grandes quantidades de glutamato durante apresentação antigênica. Surpreendentemente, essa secreção é não vesicular, mas sim dependente do $X c^{-}$ cistine/glutamate antiporter. Esse glutamato, agindo sobre os linfócitos T CD4 através do mGLUR5, foi capaz de modular a síntese de citocinas como IL-2, IL-6 e TNF- $\alpha$, além de reduzir a linfoproliferação, sendo que neste caso o receptor se mostrou o mais importante [38].

Experimentos utilizando linfócitos $\mathrm{T}$ humanos da linhagem JURKAT demonstraram também que a presença de altas concentrações de glutamato promove a síntese de IL-10, o que 
não é observado na presença de baixas concentrações. Ademais, apesar de não haver diferença na síntese de IL-8 quando comparadas baixas e altas doses, o uso do antagonista pentazocina reduziu a síntese desta citocina quando comparado ao grupo controle. Outro trabalho também utilizando células JURKAT, demonstrou que o uso dos antagonistas MK801 e AP5 impediram o ciclo celular e posteriormente induzindo apoptose, enquanto o uso dos agonistas glutamato ou NMDA resultaram num aumento significativo na adesão celular à fibronectina [39].

Alguns desses achados foram posteriormente corroborados in vivo. Utilizando o modelo de lesão por compressão, demonstrou-se de fato que linfócitos $\mathrm{T} \mathrm{CD}^{+}$infiltrantes da medula espinhal expressavam NMDAR. Mais interessante, o uso do agonista NMDA induziu uma redução significativa na frequência de células secretoras de IFN- $\gamma$ [40].

Resultados ainda mais interessantes foram descritos em um trabalho utilizando animais deficientes para o receptor mGLUR4. Inesperadamente, esses animais apresentaram um aumento da gravidade da EAE às custas de um desvio da resposta imune adaptativa de um perfil tolerogênico para um perfil ativador. De fato, animais mGLUR4 knockouts têm mais células Th17, tanto em linfonodos e baço, como infiltradas no SNC dos animais com EAE. Além disso, há um aumento significativo na síntese de citocinas pró-inflamatórias como IL-6, IL-12, IL-17, IL-23, TNF- $\alpha$ e IFN- $\gamma$ [41]. Tal trabalho foi o primeiro a demonstrar a relevância do fato de que células do sistema imune infiltrantes do SNC são alvo de mecanismos de supressão mediada por neurotransmissores dentro deste. Isso mostra a importância das interações neuro-imunes entre as células residentes do SNC e aquelas presentes no infiltrado inflamatório, principalmente se considerarmos que as células da microglia são importantes fontes de glutamato, e que sob condições inflamatórias os astrócitos cessam sua função de recaptação de glutamato e transformação em glutamina, como revisto [26].

Vale ressaltar que já havia sido descrito o potencial terapêutico de antagonistas de glutamato, como o MK801, no modelo de EAE. Todavia, à época não era conhecida a expressão de receptores NMDA em células do sistema imune, sendo que os resultados encontrados foram interpretados como secundários à ação destes em outras populações celulares, principalmente em células endoteliais do barreira hemato-encefálica [42]. 


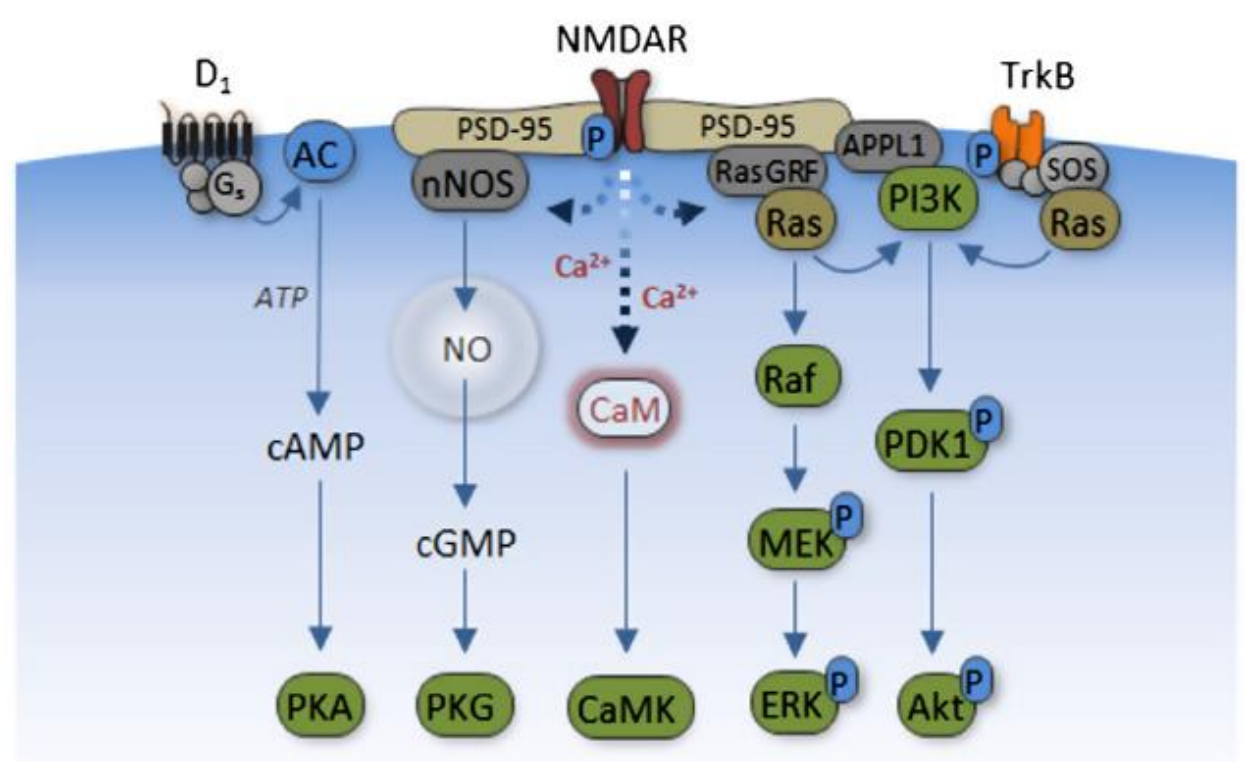

Figura 2: Vias de sinalização do NMDAR. O esquema mostra as vias de ativação utilizadas pelo receptor tipo NMDA em neurônios. Fonte: Synaptic plasticity in depression: molecular, cellular and functional correlates.Marsden et al. 2013 [43].

Outro campo ainda pouco explorado acerca do receptor tipo NMDA em células do sistema imune é o da sinalização celular. Enquanto muito já se sabe a respeito de quinases ou fatores de transcrição ativados em neurônios após o acoplamento do glutamato com o NMDAR, tais vias em células do sistema imune ainda são desconhecidas. Somado a isso, também são pouco conhecidas as repercussões desta ativação sobre o sistema imune, não sendo claro ainda se o glutamato possui um papel ativador ou supressor da resposta imune. Além desta, outras vias importantes já foram descritas após a ativação do NMDAR em células neuronais, como a via de ERK, CaMK e Akt [43], como ilustrado pela figura 2.

Por se tratar de um canal seletivo ao influxo de cálcio, a maioria das vias de sinalização ativadas pelo NMDAR são aquelas cálcio-dependentes. Dentre estas podemos citar a via NFAT (do inglês; Nuclear Factor of Activated T Cells). Curiosamente, foi demonstrado que durante o desenvolvimento do SNC a maioria dos receptores tipo NMDA são compostos pela subunidade NR2b, a qual culmina na ativação das isoformas NF-ATc3 e NF-ATc4 do NF-AT [44]. De forma interessante, a ativação de destas isoformas resulta na transcrição do gene para BDNF (do inglês; Brain Derived Neuronal Growth Factor), um importante fator antiapoptótico e de crescimento de neurônios [45]. Se tal fenômeno se repete em linfócitos T seria um fato interessante a ser descoberto, principalmente durante a neuroinflamação.

Uma via importante, e também compartilhada por linfócitos $\mathrm{T}$ e neurônios é a via de sinalização da proteína ERK (do inglês; Extracellular Signal-regulated Quinases). Enquanto em linfócitos tal via é incluída na família das MAP quinases, ou seja, quinases induzidas por 
mitógenos como fitohemaglutinina, concanavalina A ou mesmo anti-CD3 [46], em neurônios a via da ERK é disparada após ativação do receptor NMDA, como revisto [27]. Em um trabalho recente, foi demonstrado porém, que a ativação do NMDAR pode resultar no disparo de MAP quinase distintas, dependendo do estágio do desenvolvimento neural. O trabalho demonstrou que em neurônios jovens de 3 a 6 dias de desenvolvimento, o NMDAR dispara preferencialmente a via da ERK, enquanto neurônios maduros, de 9-12 dia, ativam outra MAP quinase chamada p38. Tal dicotomia fornece informações importantes, não somente na compreensão da ativação deste receptor, mas bembém para justificar o fato de que neurônios jovens são muito mais resistentes à excitoxicicidade por glutamato do que neurônios maduros. Vale ressaltar que esses resultados foram corroborados in vivo após a inoculação intrahipocampal de glutamato em camundongos jovens ou adultos [47]. É digno de nota que, assim como ERK 1,2, p38 esta também presente em linfócitos T. Porém, assim como para o NF-AT, é desconhecido o fato de que tais quinases, i.e. ERK e p38, sejam ativadas pelo glutamato nesta população celular

Mais recentemente, tem sido levantada a possibilidade de que o receptor NMDA possa ser de natureza mista, ou seja, apresentanda tanto características de um receptor ionotrópico como metabotrópico. Isso devido ao fato da fosforilação das porções intracelulares das subunidades NR1 e NR2b do NMDAR [48]. De fato, foi demonstrado que o aprendizado espacial, ou seja, animais expostos a novos locais de habitação apresentaram uma maior fosforilação destas porções no hipocampo, quando comparados a animais mantidos nas mesmas condições. Somado a isso, o grupo mostrou que tal fenômeno se dava às custas de uma ação sinérgica do NMDAR com o receptor de dopamina D1 resultando também na fosforilação de ERK 1,2 e sua subsequente ativação [49].

No intuito de contextualizar e evidenciar a importância da ativação do receptor NMDA no SNC, recentemente foi demonstrado em 1548 pacientes com esclerose múltipla que, SNPs (do inglês; Single Nucleotide Polimorphisms) nos genes codificantes das subunidades NR1 e NR2b alteram a afinidade pelo glutamato e consequentemente na capacidade de excitabilidade neuronal. Mais interessantes, essas alterações repercutiram em diferenças significativas do quadro geral dos pacientes. Nesse contexto, a variante rs4880213 de NR1 foi a mais relevante, estando relacionado à piora observada em pacientes com a forma primária-progressiva (PP-MS do inglês; Primary Progressive Multiple Sclerosis) [50]. No entanto, se tais alterações também são relevantes em células do sistema imune, e se estas contribuem para os achados clínicos é ainda um assunto a ser estudado. 
Atualmente, ainda há poucos trabalhos que tiveram o objetivo de estudar a sinalização do NMDAR em células do sistema imune. Recentemente porém, foi demonstrado in vitro, que o bloqueio do NMDAR com memantina reduz o influxo de cálcio e subsequentemente a

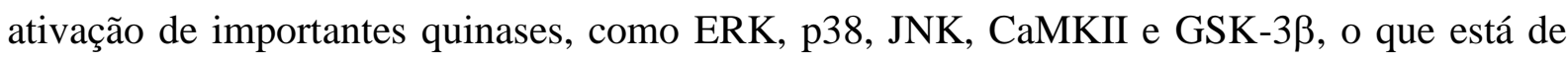
acordo com os achados em células neuronais [50]. Tais achados incitam uma nova interpretação da capacidade imunomodulatória não só do glutamato, mas também de vários outros neurotransmissores, contribuindo em muito para a ampliação da neuroimunomodulação. Corroborando a capacidade ativadora do glutamato, já foi comprovado que o tratamento com bloqueadores do receptor tipo NMDA in vivo, como MK801 ou memantina, foi eficaz na redução da resposta inflamatória e na melhora do aspecto clínico em modelo experimental de EAE [42], artrite induzida por colágeno (do inglês; Collagen Induced Arthritis) e mesmo na asma [51]. Comum a todos esse trabalhos está o fato de que o bloqueio do NMDAR é capaz de reduzir parâmetros importantes da resposta imune, como células e citocinas inflamatórias.

Em resumo, apesar de ainda haver uma literatura escassa, os tabalhos encontrados tornam inegável o fato de que o glutamato possui uma capacidade importante na modulação da resposta imune, tanto nos órgãos linfoides como dentro SNC durante processos neuroinflamatórios. Neste contexto, também pretendemos no presente trabalho avaliar o papel do receptor tipo NMDA na biologia e função de linfócitos T e sobre a modulação de alguns parâmetros importantes da resposta imune, como viabilidade celular e linfoproliferação. Além disso, buscamos corroborar os achados da literatura que mostram a ativação das MAP quinases ERK 1,2 através do NMDAR e se este possui relevância na resposta imune no modelo de EAE. 


\section{OBJETIVOS}

O presente trabalho tem como objetivo investigar as vias de modulação do NMDA sobre linfócitos T e avaliar se o efeito da ação do NMDAR sobre essas células provoca alteração na patogênese da EAE (Encefalomielite Experimental Auto-Imune). 


\section{MATERIAIS E MÉTODOS}

\subsection{Cultura celular e estimulação in vitro}

Clones de linfócitos T CD4 específicos para ovalbumina (OVA) da linhagem DO11.10 foram gentilmente cedidos pelo Prof. João Gustavo Pessini Amarante-Mendes. As mesmas foram mantidas e repicadas periodicamente em meio RPMI suplementado com $10 \%$ de soro fetal bovino (SFB) e $50 \mu \mathrm{g} / \mathrm{mL}$ de streptomicina. Utilizamos $5.10^{6}$ células por poço em placas de 48 poços. As mesmas foram ativadas mediante estímulo com $1 \mu \mathrm{g} / \mathrm{mL}$ de anti-CD3 em placas de 48 poços previamente sensibilizadas. As culturas foram mantidas na presença ou não de $10 \mu \mathrm{M}$ de NMDA ( $N$-metil-D-aspartato) e $100 \mu \mathrm{M}$ de MK801 durante 24 horas. Após esse período as células foram extraídas e preparadas de acordo com protocolos específicos para PCR, Imunofluorescência ou Western Blot.

Para os experimentos ex vivo, linfócitos T CD4 e T CD8 foram extraidos de baço de camundongos fêmeas C57Bl/6 de 6-8 semanas. Para tanto foram utilizados kits de separação por beads magnéticos com o kit L3T4 (MACS Miltenyl Biotec, Bergish Gladbach, NW., Alemanha) específicos para separar linfócitos T CD4. Após a separação, o grau de pureza foi verificado através de marcação das células com anticorpo anti-CD4 e leitura por aparelho FACS Accuri C6 Cytometer da marca BD (BD Bioseciences, San Diego, CA., Estados Unidos). O grau de pureza das células, aferido pelo aparelho, foi próximo a 90\%. Em seguida, as células foram colocadas em placas de 96 poços, numa quantidade de $4.10^{6}$ células por poço com meio RPMI suplementado com SFB a 10\%. Ao meio, foram adicionados ou não os seguintes estímulos: NMDA a 10n $\mu \mathrm{M}, \mathrm{MK}$ a 100n $\mu \mathrm{M}$, ou NMDA a 10n $\mu \mathrm{M}$ com MK a $100 \mu \mathrm{M}$. A placa foi posta para incubar por 6 horas e, após esse tempo, as células foram removidas e submetidas a preparo de acordo com protocolos de PCR, Imunofluorescência ou Western Blot.

\subsection{PCR em Tempo Real}

Células de linhagens DO11.10 e T CD4 ex vivo foram homogenizadas e mantidas em temperatura ambiente (TA) por 5 minutos. Após esse tempo, adicionou-se $200 \mu \mathrm{L}$ de clorofórmio seguido de incubação de 2 a 3 minutos em TA. Esta solução foi centrifugada a $12000 \mathrm{~g}, 15$ minutos, $4{ }^{\circ} \mathrm{C}$ e o sobrenadante transferido para um tubo novo ao qual adicionouse $0,5 \mathrm{~mL}$ de isopropanol. $\mathrm{O}$ eppendor foi agitado em vórtex por 10 segundos. Em seguida, a solução foi incubada a TA em um período de 45 minutos a 1 hora, e então centrifugada 
novamente a $12000 \mathrm{~g}, 15$ minutos, $4{ }^{\circ} \mathrm{C}$ tendo o seu sobrenadante removido cuidadosamente, evitando o contato com o precipitado de RNA. Posteriormente, adicionou-se $1 \mathrm{ml}$ de etanol 75 $\%$ e centrifugado a uma temperatura de $4{ }^{\circ} \mathrm{C}, 5$ minutos a $7500 \mathrm{~g}$ e então deixado na bancada para que pudesse secar e posteriormente ressuspendido em $25 \mu \mathrm{L}$ de água livre de RNAse e DNAse (Gibco).

A síntese de cDNA foi feita pela utilização da transcriptase reversa SuperScript III, onde adicionou-se a eppendorfs isentos de RNAse/DNAse, devidamente identificados, $1 \mu \mathrm{L}$ de Oligo (DT) $50 \mu \mathrm{M}, 1 \mu \mathrm{L}$ de dNTP mix $10 \mathrm{mM}$ contendo $(10 \mathrm{mM}$ de dATP, dTTP, dCTP, dGTP), 1 a $5 \mu \mathrm{g}$ de mRNA em $13 \mu \mathrm{L}$ de água isenta de RNAse/DNAse, misturando-os com a pipeta. Posteriormente, estes tubos foram aquecidos no termociclador a $65^{\circ} \mathrm{C}$ por 5 minutos seguidos de uma incubação no gelo por, no mínimo, 1 minuto. Após este processo, foram adicionados aos tubos $4 \mu \mathrm{L}$ de 5 X First-Strand Buffer, $1 \mu \mathrm{L}$ de DTT 0,1 M, $1 \mu \mathrm{L}$ de SuperScript III RT $200 \mathrm{U} / \mu \mathrm{L}$, misturados com pipeta e vortex rapidamente. Em seguida os tubos foram incubados a $50{ }^{\circ} \mathrm{C}$ por 60 minutos. Para inativar a reação, os tubos foram aquecidos a $70{ }^{\circ} \mathrm{C}$ por 15 minutos e então o cDNA foi guardado em freezer a $-20^{\circ} \mathrm{C}$. (Todos os reagentes para PCR são produtos da empresa Life Technologies, Carlsbad, CA., Estados Unidos).

Para a realização do PCR em Tempo Real, foi utilizado $1 \mu \mathrm{L}$ de $20 X$ TaqMan Gene Expression Assay, $9 \mu \mathrm{L}$ de cDNA, água RNAse/DNAse free e $10 \mu \mathrm{L}$ de $2 X$ TaqMan Gene Expression Master Mix colocados em tubos eppendorf, totalizando um volume de $20 \mu \mathrm{L}$ para cada solução que foram então levadas ao termociclador Applied Biosystems 7900HT Real-Time PCR System ${ }^{\circledR}$. As curvas foram normalizadas à expressão de Beta Actina.

Primers utlizados para experimentos de PCR em Tempo Real:

- PCR de células DO11.10: grin1, IL-2, IL-10, SOCS-3, RORc

- PCR de células T CD4 ex vivo: grin1

\subsection{Imunofluorescência}

Células de linhagem DO11.10 e T CD4 ex vivo foram depositadas em lâminas comuns de comuns por citospin. As lâminas foram postas para secar por cerca de 2 minutos e área ao redor de onde as células se depositaram foi marcada com caneta hidrofóbica. Nas lâminas secas, aplicou-se metanol puro no quadrante marcado com caneta hidrofóbica para permitir a fixação das células. Após esse tempo, a lâmina foi lavada por 3 vezes de 10 minutos com PBS $1 \mathrm{X}$ e então aplicou-se solução de bloqueio (solução de 5\% em PBS 1X, com Triton X-100 a 0,01 \%) e as lâminas foram deixadas incubando por 2 horas à TA. Em seguida, foi aplicada solução 
com anticorpo primário diluído em soro de bloqueio $1 \%$ e foi mantida overnight (12 a 16 h) em geladeira. No dia seguinte, as lâminas foram lavadas por 3 vezes de 10 min com PBS 1X e postas para incubar por 2 horas com anticorpo secundário, em TA e protegidas da luz. Em seguida, as lâminas foram lavadas por 3 vezes de 5 minutos em PBS 1X e em seguida aplicouse solução do marcador nuclear DAPI, da empresa Life Technologies, na proporção de 1 para 100.000 em PBS 1X + Triton X-100 0,01 \%. As lâminas foram lavadas por 4 vezes de 10 minutos em PBS 1X, montadas com Vecta Shield, da empresa Vector Laboratories (Vector Laboratories, Burlingame, CA., Estados Unidos) e lamínula, seladas nas extremidades laterais com esmalte incolor e depositadas em um recipiente escuro dentro de geladeira para posterior revelação em microscópio de imunofluorescência.

\subsection{Western Blot}

Células de linhagem DO11.10 foram preparadas para extração de proteínas com $1 \mathrm{ml}$ de Tampão RIPA + 1 comprimido inibidor de proteases +1 comprimido inibidor de fosfatases. As amostras foram inseridas em tubos específicos para Precellys e levadas ao aparelho para maceração. Em seguida, as células foram centrigadas por 10 minutos a $3000 \mathrm{rpm}$ em centrífuga refrigerada $\left(4\right.$ a $\left.8{ }^{\circ} \mathrm{C}\right)$. O sobrenadante foi coletado e levado para congelar em freezer $-80{ }^{\circ} \mathrm{C}$.

A dosagem de proteínas nas amostras foi realizada através da utilização do kit de dosagem de proteínas BCA Protein Assay Reagent da empresa Thermo Scientific (Thermo Scientific, Waltham, MA., Estados Unidos). A partir dos resultados, foi calculada a concentração de proteína e o volume necessário para a obtenção de $25 \mu \mathrm{g}$ de proteína para o ensaio de Western Blot, para cada amostra.

Para a eletroforese, as amostras foram diluídas até um volume de $12,5 \mu \mathrm{L}$ e a esse foram adicionados $12,5 \mu \mathrm{L}$ de tampão $2 \mathrm{X}$. A mistura foi aquecida a $95{ }^{\circ} \mathrm{C}$ por 5 minutos em um aparelho termociclador. $\mathrm{O}$ volume de $20 \mu \mathrm{L}$ de cada uma amostras foi depositado em poços separados de gel de empacotamento em uma cuba para Western Blot. Após a depoisção das amostras, foi colocado na cuba o Tampão de Corrida 1X e o aparelho de Western Blot foi ligado a $400{ }^{\circ} \mathrm{C}$ e $80 \mathrm{~V}$ para o nivelamento das bandas ao nível do gel de corrida. Em seguida, o aparelho foi ajustado para $110 \mathrm{~V}$ por 1 hora.

Após a corrida, o gel de Western Blot foi preparado para transferência em uma cuba de Western Blot com o aparato de transferência que inclui esponjas, papel filtro, membrana de nitrocelulose e placa suporte. Tampão de Transferência $1 \mathrm{X}$ e gelo foram colocado na cuba e o aparelho foi ligado a $60 \mathrm{~V}$ por 1 hora. 
O bloqueio da membrana de Western Blot foi realizado em aparelho de SNAP ID da empresa Millipore (Millipore, Billerica, MA., Estados Unidos) com solução de albumina 1\% (0,5 g de albumina em $50 \mathrm{~mL}$ TB-T) por 1 hora. A incubação com anticorpo primário, diluído a 1:1000, foi feita no mesmo aparelho por 10 minutos. Em seguida, a membrana foi lavada por três vezes com TBS-T e incubada com anticorpo secundário, diluído a 1:10.000, por 10 minutos. Após a incubação, a membrana foi lavada por três vezes com TBS-T.

Para a revelação, aplicou-se solução reveladora de ECL sobre a membrana e esta foi colocada em aparelho de G-BOX para a captação da imagem de Western Blot.

Anticorpos utilizados para ensaios de Western Blot:

- Western Blot para a via de sinalização de MAP Quinase em células DO11.10: ERK-1 Total, ERK-2 Total, ERK-1 difosfo e ERK-2 difosfo, beta-actina

\subsection{Imunização para Indução de EAE (Encefalomielite Experimental Auto-Imune)}

Camundongos fêmeas de linhagem C57BL/6 foram separadas em dois grupos experimentais: grupo controle e grupo de tratado com MK801. Os animais foram imunizados subcutanemente na base da caudal com $200 \mu \mathrm{L}$ de emulsão de imunização contendo: i) grupo controle: $15 \mu \mathrm{L}$ de MOG (solução estoque de 10mg/mL), $100 \mu \mathrm{L}$ de CFA (Complete Freund Adjuvant), $85 \mu \mathrm{L}$ de PBS; ii)grupo de tratamento com MK801: $15 \mu \mathrm{L}$ de MOG (solução estoque de 10mg/mL), $100 \mu \mathrm{L}$ de CFA, $67 \mu \mathrm{L}$ de MK801 (solução estoque de 10mM), $18 \mu \mathrm{L}$ de PBS 1X. As emulsões de imunização foram preparadas em seringas de vidro e emulsificadas durante 15 minutos. Em seguida, as mesmas foram levadas à geladeira por cerca de 30 minutos e então $200 \mu \mathrm{L}$ de emulsão foram injetados em cada animal. Os animais também receberam duas doses de 0,2 ng de toxina de Bordetella pertussis 0 e 48 horas pós-imunização. Os animais do grupo MK801 foram tratados com MK801 (0,3mg/kg), sendo a primeira dose incluída na emulsão e as três doses subsequentes por via intraperitoneal. Os animais foram acompanhados diariamente e o grau de doença distribuído da seguinte forma: 0) sem doença 1) perda do tônus da cauda 2) flacidez ou fraqueza dos membros posteriores 3) paralisia dos membros posteriores 4) fraqueza de membros anteriores 5) paralisia de membros anteriores ou morte. Todos os experimentos foram realizados com a aprovação da Comissão de Ética no Uso de Animais (CEUA) em 16/10/2012, sob registro 174 fls 114 livro 2. 


\subsection{Citometria de Fluxo}

Esplenócitos totais foram obtidos de animais B57BL/6. Após maceração e lise de hemácias, as amostras foram lavadas com PBS e centrifugadas a $450 \mathrm{~g}$ por 5 minutos. Em seguida, as amostras foram ressuspendidas em meio DMEM 10\% SFB (Soro Fetal Bovino). As células foram então contadas e utilizadas para análise de:

i) Para ensaios de proliferação, esplenócitos totais foram previamente marcados com CFSE $2 \mu \mathrm{M}$ durante 20 minutos a $37{ }^{\circ} \mathrm{C}$. Posteriormente, as células foram lavadas com meio DMEM contendo SFB $10 \%$ e plaqueadas a $1.10^{6}$ células por poço em placas de 96 wells. Em seguida, as células foram estimuladas ou não com $1 \mu \mathrm{g} / \mathrm{mL}$ de anti-CD3 na presença ou não de NMDA $10 \mu \mathrm{M}$ ou $100 \mu \mathrm{M}$ e MK801 $100 \mu \mathrm{M}, 200 \mu \mathrm{M}, 500 \mu \mathrm{M}$ e $1000 \mu \mathrm{M}$ durante 72 horas. Após o tempo de incubação, a placa foi submetida a centrifugação de $450 \mathrm{~g}$ por 5 minutos a uma temperatura de $4{ }^{\circ} \mathrm{C}$. Em seguida, as mesmas foram lavadas com PBS $2 \%$ SFB, centrifugadas a $450 \mathrm{~g}$ por 5 minutos à $4{ }^{\circ} \mathrm{C}$. O sobrenadante foi descartado e as amostras ressuspendidas em $300 \mu \mathrm{L}$ de paraformaldeído $1 \%$ e adquiridas no citômetro de fluxo BD Accuri. Foram adquiridos 5000 eventos em gate de CD4 ou CD8.

ii) Para a análise de células em apoptose $1.10^{6}$ esplenócitos totais foram incubados com Anexina V Pe em tampão de ligação durante 20 minutos a temperatura ambiente. Em seguida, as amostras foram lavadas em PBS 2\% SFB, centrifugadas a $450 \mathrm{~g}$ por 5 minutos à $4{ }^{\circ} \mathrm{C}$, e adquiridas no citômetro de fluxo BD Accuri. Foram adquiridos 5000 eventos em gate de CD4 ou CD8.

\subsection{Análise Estatística}

As análises estatísticas foram realizadas com o auxílio do software computacional Graphpad Prism (Graphpad Software Incorporation®) versão 4.0. Os testes One-way ANOVA foram utilizados, seguidos pelo pós-teste de Tukey. Para a análise da curva de EAE foi utilizado o teste Two-way ANOVA. Os dados foram apresentados como média \pm erro padrão nas curvas de doença. Valores $\mathrm{p}<0,05$ foram considerados estatisticamente significativos. 


\section{RESULTADOS}

\subsection{Linfócitos T CD4 murinos expressam NMDAR}

Iniciamos nossos estudos avaliando a expressão do receptor NMDAR em linfócitos T CD4 murinos ativados ou em repouso. Para tanto, linfócitos T CD4 esplênicos foram isolados por beads magnéticos e submetidos ao protocolo de imunofluorescência para detecção da subunidade NR1 do receptor NMDAR, como descrito nos materiais e métodos (Figura 3A). No intuito de avaliarmos se o perfil de ativação celular repercute numa modulação da expressão do NMDAR, utilizamos linfócitos T CD4 da linhagem DO11.10 ativados ou não in vitro com antiCD3 $(1 \mu \mathrm{g} / \mathrm{mL})$. Nossos resultados mostram não haver diferença na expressão de grin1 em linfócitos T CD4 em repouso se comparados a linfócitos T CD4 ativados com anti-CD3 (Figura 3B). Todavia, há um grande aumento na transcrição do gene grinl em linfócitos T CD4 em repouso cultivados na presença de NMDA $(10 \mu \mathrm{M})$, o qual é revertido na presença do antagonista MK801 (100 $\mu \mathrm{M})$. Tal aumento não é observado em linfócitos T CD4 ativados (Figura 3B).
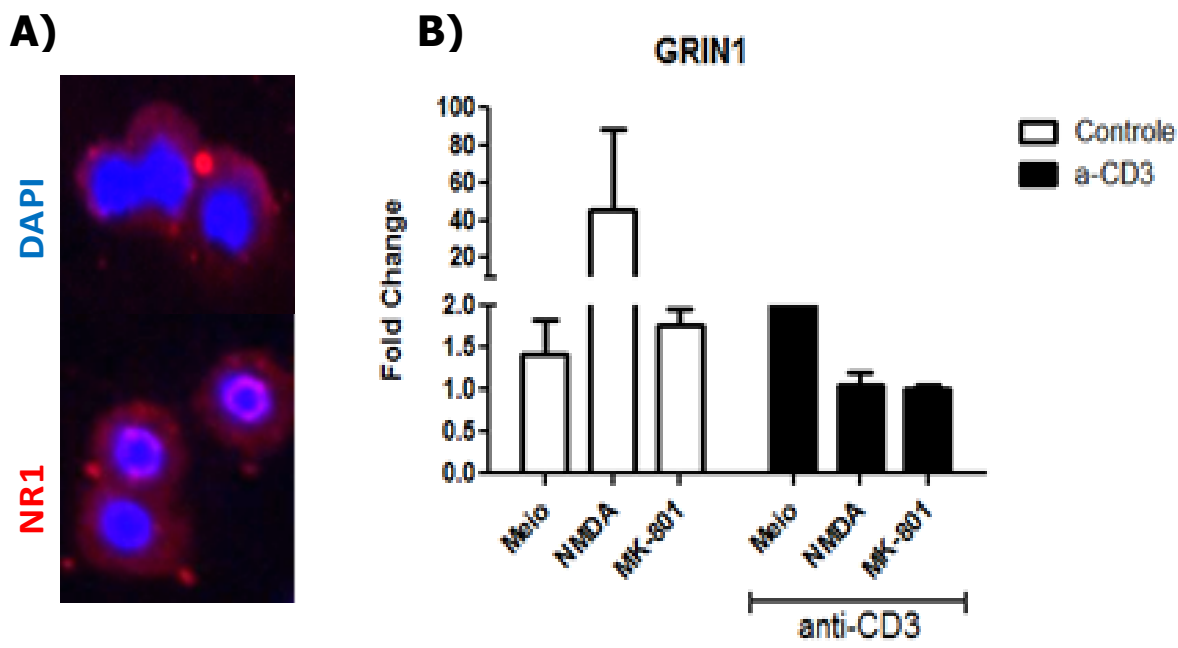

Figura 3: Expressão da subunidade NR1 do receptor NMDAR em linfócitos T CD4 murinos. a) linfócitos T $\mathrm{CD}^{+}$de animais C57B1/6 foram isolados por separação magnética e posteriormente submetidas ao protocolo de imunofluorescência para detecção de NR1 (anti-NR1 PE) e núcleos celulares (DAPI). b) linfócitos T CD4 ${ }^{+}$da linhagem DO 11.10 foram estimulados ou não com anti-CD3 $(1 \mu \mathrm{g} / \mathrm{mL})$ na presença ou não de NMDA $(10 \mu \mathrm{M})$ ou MK801 $(100 \mu \mathrm{M})$ durante 24 horas. Posteriormente as células foram coletadas e submetidas à extração de RNA para a análise da expressão do gene grin1. As reações foram normalizadas frente à beta actina. 


\subsection{Estímulo por N-metil-D-Aspartato em células DO11.10 modula a transcrição gênica}

Após confirmarmos a presença de receptores do tipo NMDAR em células DO11.10, avaliamos a transcrição de genes para citocinas pró- e anti-inflamatórias na presença do agonista ou do antagonista de NMDAR, por PCR em tempo real. As células DO 11.10 ativadas por anti-CD3 na presença de NMDA apresentaram redução nos transcritos para a citocina IL10 (figura 4B) e também para o molécula supressora SOCS-3 (figura 4D), capaz de reduzir a sinalização de citocinas através da desfosforilação e ubiquitinação dos fatores de transcrição STATs.

O gene RORc, que codifica par o receptor nuclear ROR $\gamma \mathrm{t}$, um marcador de células Th17, teve sua expressão significantemente aumentada na presença de NMDA, a qual foi revertida pela presença de MK-801 em células naive, ao passo que em células ativadas observamos o efeito oposto (figura 4C). Como esperado, a citocina IL-2 apresentou aumento na transcrição quando células DO 11.10 foram ativadas com anti-CD3. Quanto ao efeito do agonista ou do antagonista de NMDA, a diferença de expressão foi mais marcante em células ativadas. $\mathrm{O}$ estímulo com o agonista de NMDAR reduziu nessas células a expressão de IL-2, enquando o bloqueio com MK-801 provocou aumento de expressão (figura 4A).

A)

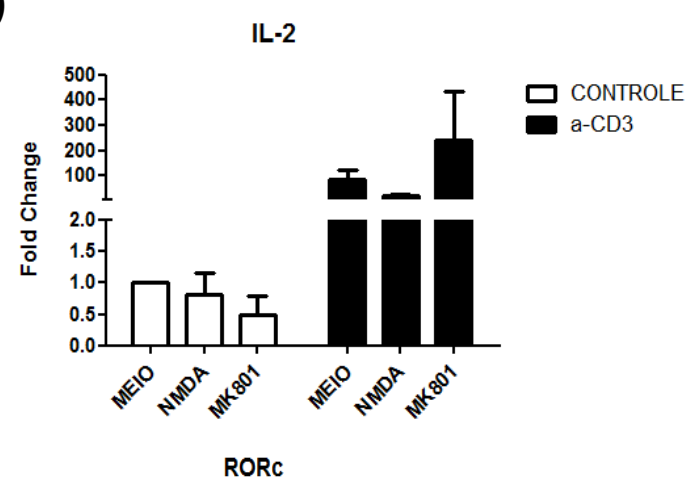

B) $\quad$ LL-10
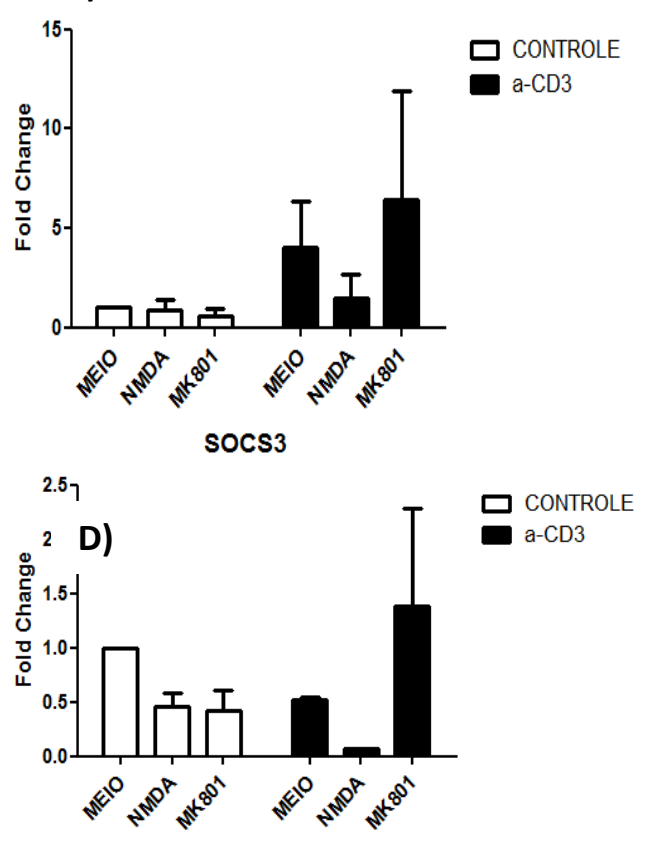

Figura 4: Expressão dos genes para IL-2, IL-10, RORc e SOCS-3 em células DO11.10 ativadas in vitro. Células DO.11.10 foram plaqueadas em placas sensibilizadas ou não com anti-CD3, na presença ou não de NMDA e MK-801 durante 48 horas. a. Expressão de citocina IL-2; b. Expressão de citocina IL-10; c. Expressão do gene RORc, d. Expressão do gene SOCS-3. Os resultados foram normalizados frente à expressão de $\beta$-actina. Two-way ANOVA.p $<0,05$. 


\subsection{NMDAR em linfócitos T CD4 ativa a via de MAP quinases}

A ativação de linfócitos T através do TCR culmina no disparo de vias intracelulares e

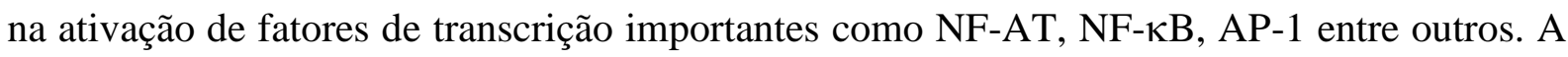
ativação de tais fatores, usualmente depende da função de proteínas quinases ou proteínas fosfatases intracelulares. Dentre estas, podemos citar as MAP quinases ERK-1 e ERK-2 como algumas das mais importantes. Nesse contexto, nosso próximo passo foi avaliar se o receptor NMDAR é capaz de modular a via de MAP quinases, mais especificamente ERK-1 e ERK-2 em linfócitos T CD4 da linhagem DO11.10. As células foram plaqueadas em placas sensibilizadas ou não com anti-CD3 $(1 \mu \mathrm{g} / \mathrm{mL})$ na presença de NMDA $(10 \mu \mathrm{M})$ ou MK801 $(100 \mu \mathrm{M})$. Como podemos observar na figura 5, o estímulo com NMDA foi capaz de aumentar a fosforilação de ERK-1 (Figura 5 - blot inferior) mesmo na ausência de anti-CD3, a qual foi revertida pela presença de MK801. Por outro lado, quando avaliamos as células ativadas na presença de anti-CD3 + NMDA, observa-se um aumento na fosforilação de ERK-2. Da mesma forma, a presença de MK801 fez a fosforilação de ERK-2 retornar ao nível basal, mesmo sob a condição NMDA+MK801 (Figura 5).

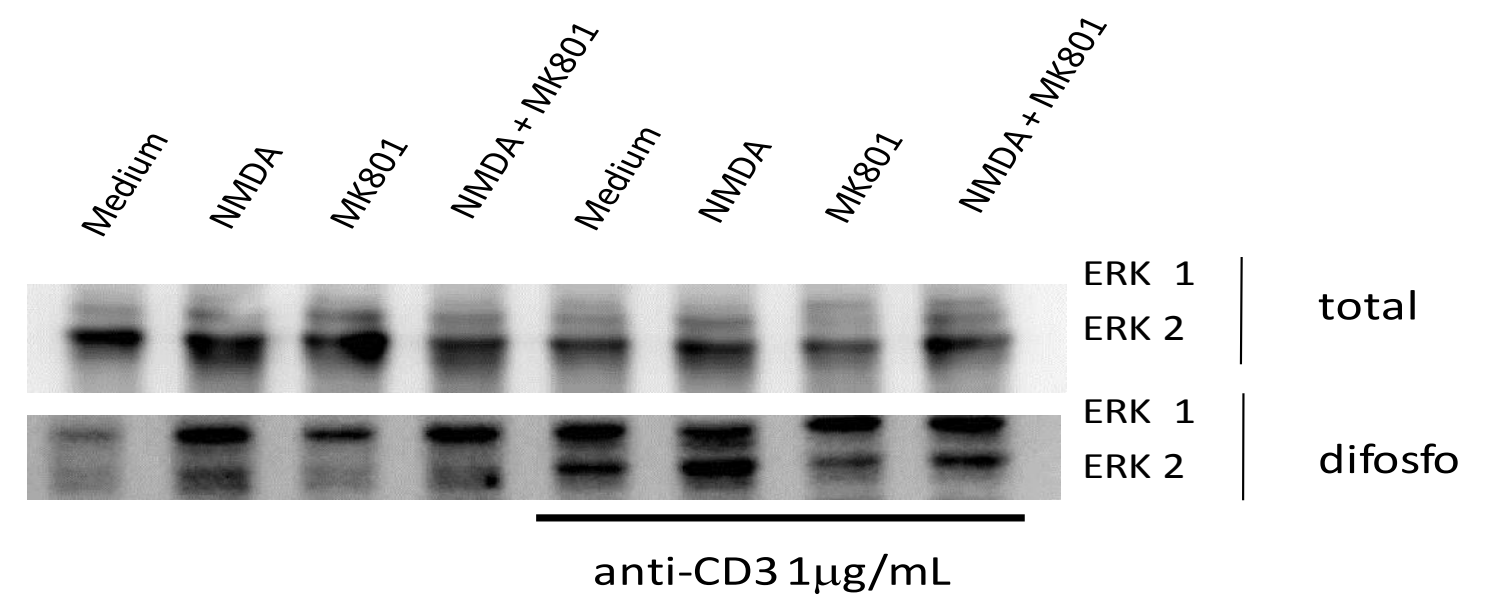

Figura 5: Ativação da via de sinalização das MAP Quinases ERK-1 e ERK-2 pelo NMDAR. Células DO.11.10 foram plaqueadas em placas sensibilizadas ou não com anti-CD3, na presença ou não de NMDA e MK-801 durante 48 horas. Posteriormente as células foram coletadas e submetidas ao protocolo para extração de proteínas e avaliadas por western blot para a expressão de ERK-1, ERK-2, e fosfo-ERK-1 e fosfo-ERK-2.

\subsection{Bloqueio da ativação do NMDAR reduz a proliferação de linfócitos T CD4 e T CD8}

Mediante a possibilidade de inibição da via de MAP por morte celular, decidimos avaliar a linfoproliferação de linfócitos T CD4 e CD8 em culturas de esplenócitos totais ativados com anti-CD3 na presença de NMDA ou MK801. Os esplenócitos foram adquiridos, marcados e 
plaqueados como descrito nos materiais e métodos. Após 72 horas de culturas, as células foram coletadas e avaliadas por citometria de fluxo. Como podemos observar na figura 6 e 7 o bloqueio do receptor NMDAR com as maiores concentrações de MK801 (500 e $1000 \mu \mathrm{M})$ foi capaz de impedir a proliferação dos linfócitos T CD4 ativados com anti-CD3, tanto avaliandose o MFI do CFSE (figura 6) como a porcentagem de células em proliferação (figura 7).

\subsection{Redução da linfoproliferação se dá às custas de aumento na apoptose}

Para avaliarmos se a redução na proliferação celular se dava às custas de indução de anergia ou morte celular, resolvemos avaliar a taxa de apoptose em linfócitos T CD4 e CD8 ativados na presença do agonista NMDA ou do antagonista MK801 do receptor NMDAR. Pode-se observar nas figuras 8A e 9 que as doses de MK801 que induziram a redução na proliferação celular também apresentaram as maiores taxas de células em apoptose para linfócitos T CD4. Os resultados células T CD8 marcadas com anexina mostram que esse tipo celular também é suscetível à apoptose por aumento de concentração de MK801 no meio (figura 8B), uma vez que quantidades crescentes de MK801 induzem a uma taxa maior de apoptose. Para confirmar tais achados, avaliamos os esplenócitos totais quanto ao tamanho e granulosidade com gate em células viáveis, excluindo-se os debris. Como demonstra a figura 9, as maiores concentrações induziram uma drástica redução no tamanho e granulosidade celular assim como na frequência de células vivas. Essas mesmas amostras foram também submetidas à marcação com 7-AAD para viabilidade celular e como mostram os resultados da figura 10 , de fato as doses de 500 e $1000 \mu \mathrm{M}$ induzem aumento na morte celular. 
6
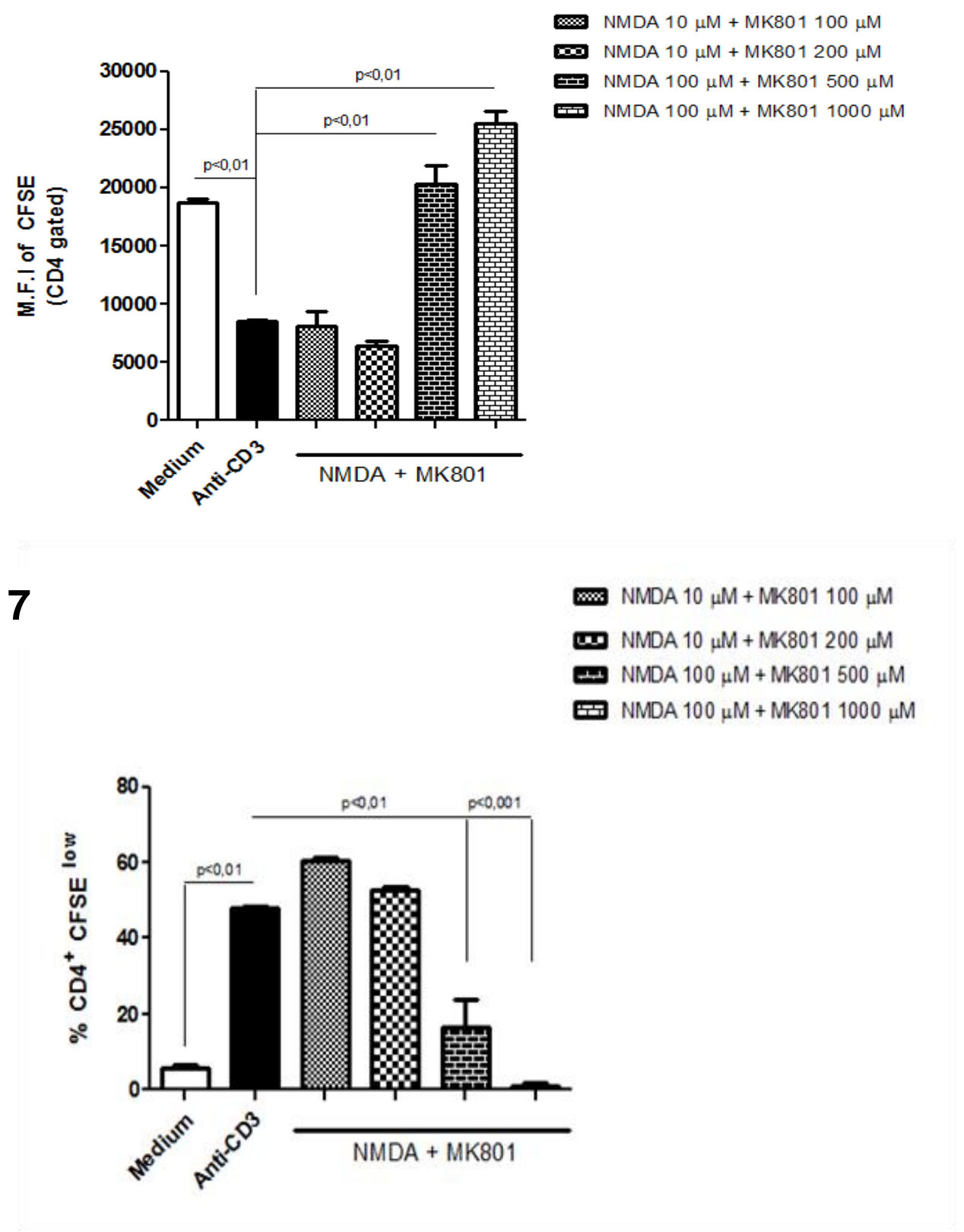

Figura 6: Linfoproliferação de Linfócitos T CD4 em culturas de esplenócitos totais. (média da intensidade de fluorescência (MFI) do CFSE) $1.10^{6}$ esplenócitos totais foram marcados com CFSE e plaqueados em placas de 98 poços na presença de anti-CD3 $(1 \mu \mathrm{g} / \mathrm{mL})$ na presença de NMDA $(10 \mu \mathrm{M}$ ou $100 \mu \mathrm{M})$ e MK801 $(100 \mu \mathrm{M}, 200 \mu \mathrm{M}, 500 \mu \mathrm{M}$ e $1000 \mu \mathrm{M})$ durante 72 horas. Após esse período as células foram marcadas com anti-CD4 PercP e anti-CD8 Pe e avaliadas por citometria de fluxo.

Figura 7: Linfoproliferação de Linfócitos T CD4 em culturas de esplenócitos totais. (frequência de células CFSE $^{\text {low }}$ que sofreram divisão celular. Dados representativos de dois experimentos em triplicatas. Two-ANOVA. $\mathrm{p}<0.01$.) $1.10^{6}$ esplenócitos totais foram marcados com CFSE e plaqueados em placas de 98 poços na presença de anti-CD3 $(1 \mu \mathrm{g} / \mathrm{mL})$ na presença de NMDA $(10 \mu \mathrm{M}$ ou $100 \mu \mathrm{M}) \mathrm{e}$ MK801 $(100 \mu \mathrm{M}, 200 \mu \mathrm{M}, 500 \mu \mathrm{M}$ e $1000 \mu \mathrm{M})$ durante 72 horas. Após esse período as células foram marcadas com anti-CD4 PercP e anti-CD8 Pe e avaliadas por citometria de fluxo. Em A) média da intensidade de fluorescência (MFI) do CFSE e em B) frequência de células CFSE ${ }^{\text {low }}$ que sofreram divisão celular. Dados representativos de dois experimentos em triplicatas. Two-ANOVA. p<0.01. 
A)

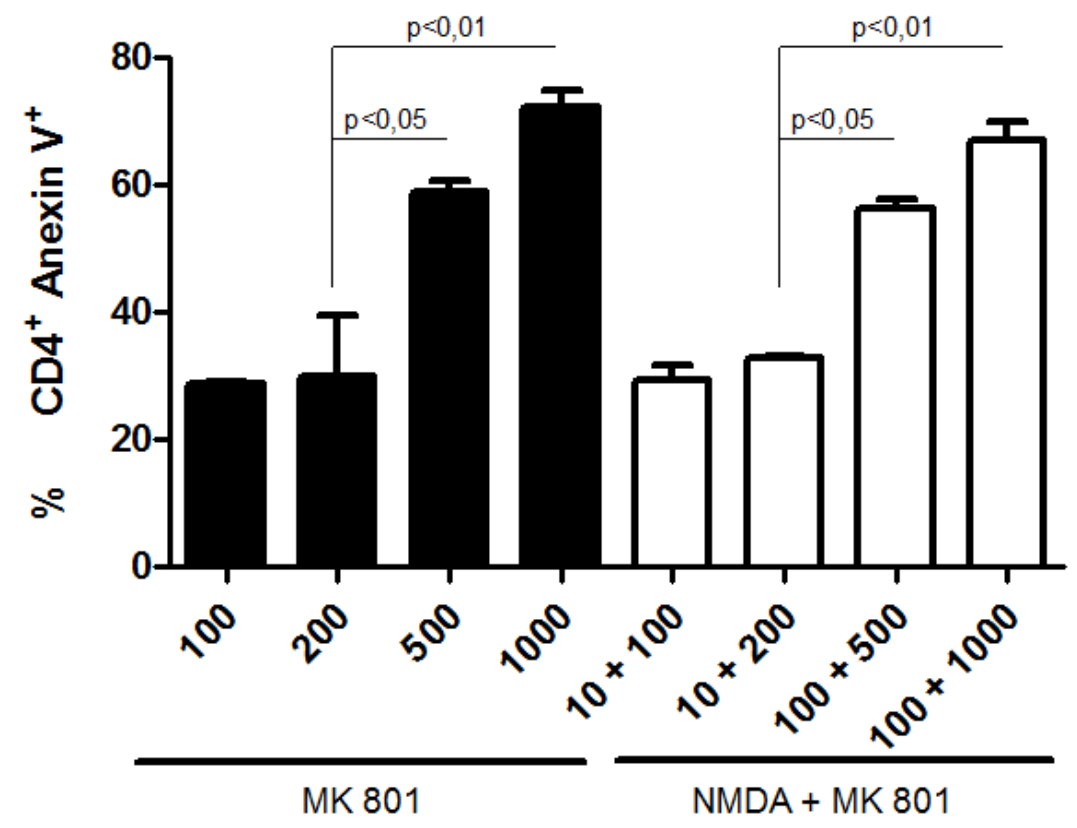

B)

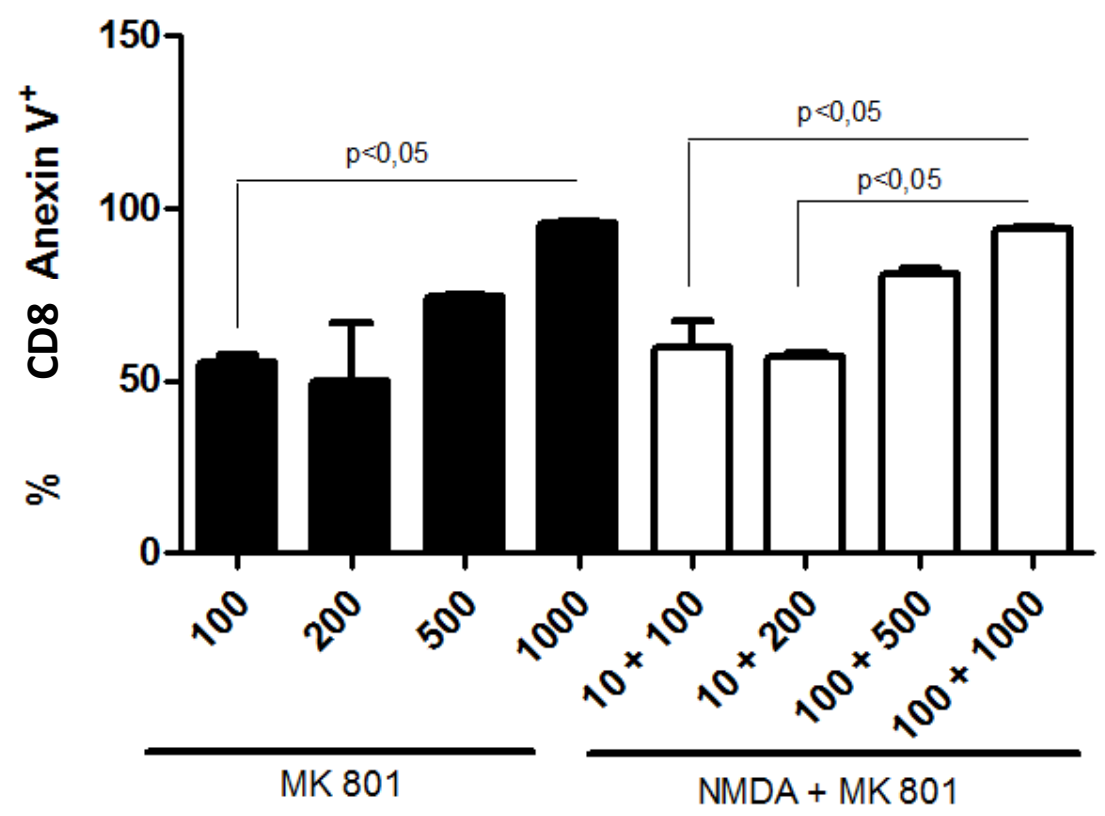

Figura 8: Bloqueio do NMDAR Induz Apoptose em Linfócitos T CD4 e CD8 de em culturas de esplenócitos totais. $1.10^{6}$ esplenócitos totais foram plaqueados em placas de 98 poços na presença de anti-CD3 $(1 \mu \mathrm{g} / \mathrm{mL})$ na presença de NMDA $(10 \mu \mathrm{M}$ ou $100 \mu \mathrm{M})$ e MK801 $(100 \mu \mathrm{M}, 200 \mu \mathrm{M}, 500 \mu \mathrm{M}$ e $1000 \mu \mathrm{M}$ ) durante 24 horas. Após esse período as células foram marcadas com anti-CD4 PercP, antiCD8 Pe e anexina V - FITC e avaliadas por citometria de fluxo. Em A e B) frequência de linfócitos T CD4 e CD8 respectivamente. Dados representativos de dois experimentos em triplicatas. TwoANOVA. $\mathrm{p}<0.01$. 

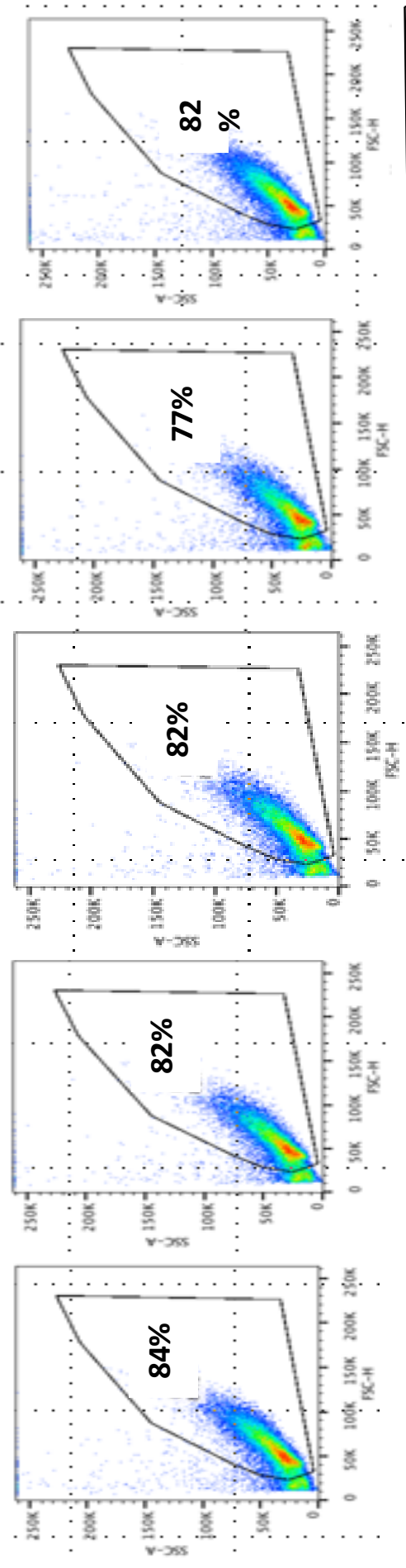
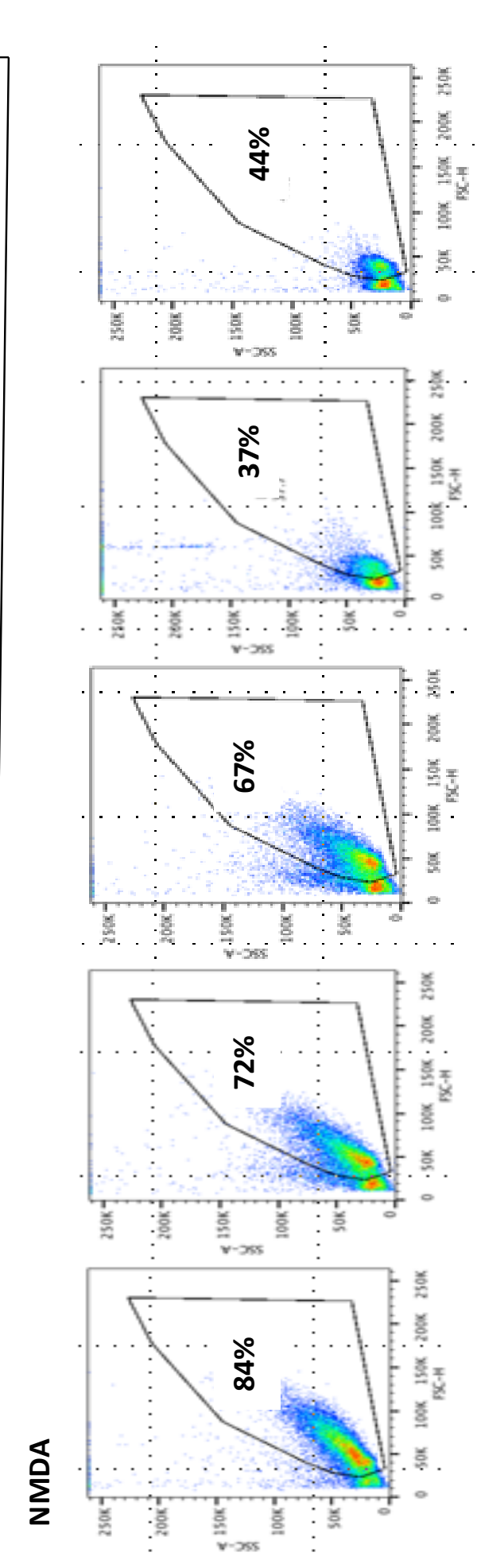

ләңґеэS әр!S
号

홍

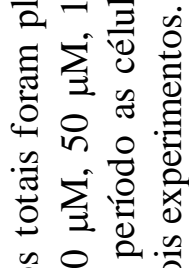

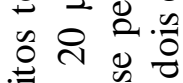

is के

造造造起

\&会额

- Z

. 월 일

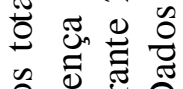

के

근

范焉

힝ㅇㅇㅇㅇㅇ

结志

ํㅠㄹ 일 0

․ㅜㅇ

ำ

$\Xi \sum_{\Xi}$

$\propto$ ส

这。

实芯

항

는

过范

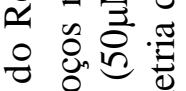

○ ह

용 $\infty$ 。

음

๑

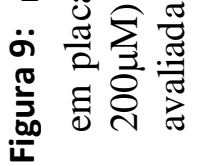



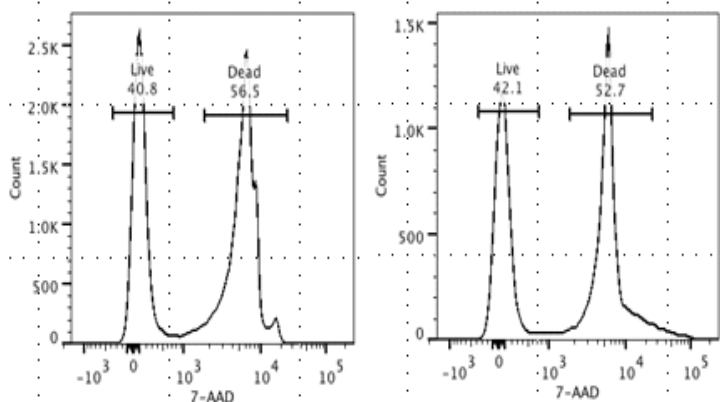

Meio

Anti-CD3
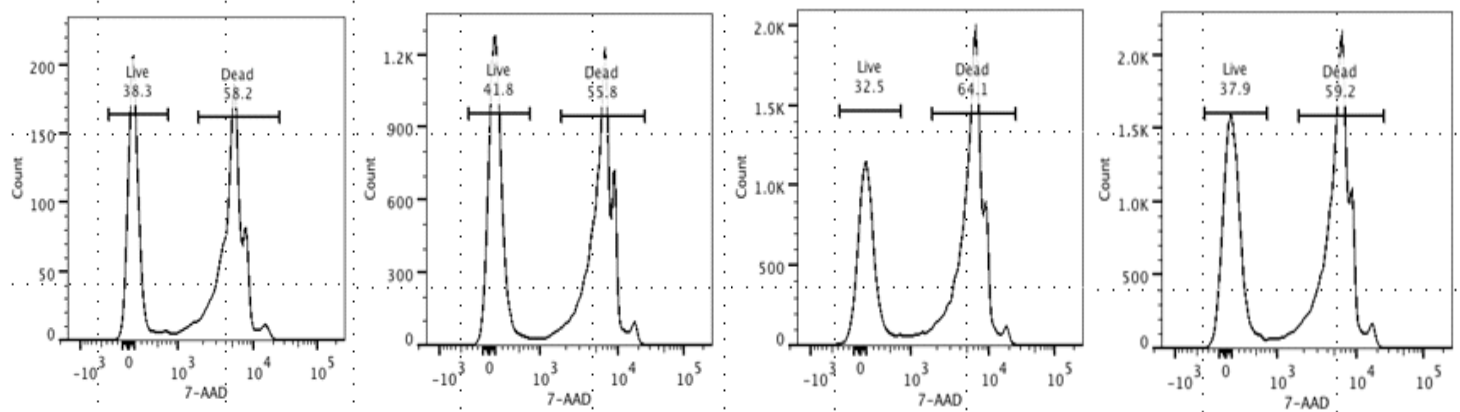

NMDA
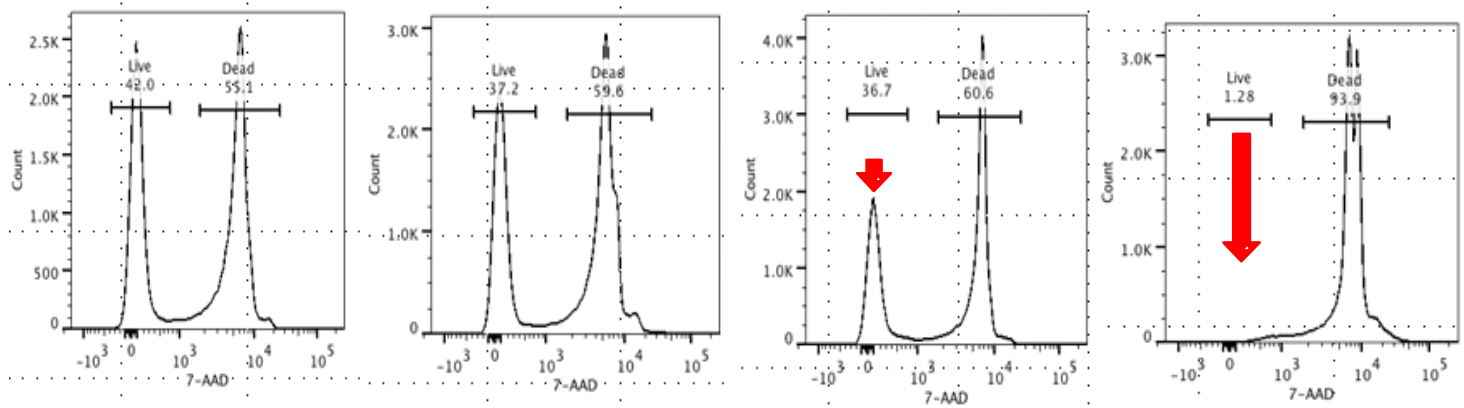

NMDA + MK801

Figura 10: Bloqeio do Receptor NDMAR induz redução na viabilidade celular de esplenócitos totais. $1.10^{6}$ esplenócitos totais foram plaqueados em placas de 98 poços na presença de anti-CD3 $(1 \mu \mathrm{g} / \mathrm{mL})$ e na presença de NMDA $(10 \mu \mathrm{M}, 20 \mu \mathrm{M}, 50 \mu \mathrm{M}, 100 \mu \mathrm{M}$ e $200 \mu \mathrm{M})$ e MK801 $(50 \mu \mathrm{M}, 100 \mu \mathrm{M}, 200 \mu \mathrm{M}, 500 \mu \mathrm{M}$ e $1000 \mu \mathrm{M})$ durante 24 horas. Após esse período as células foram marcadas com 7-AAD e avaliadas por citometria de fluxo. Dados representativos de dois experimentos. As setas demonstram a redução nas células 7-AAD ${ }^{\text {neg. }}$ 


\subsection{Tratamento com MK801 in vivo reduz a gravidade da encefalomielite experimental auto-imune}

Nossos resultados in vitro demonstram que o bloqueio do receptor NMDAR com altas doses de MK801 induz uma acentuada redução na viabilidade celular, tanto em esplenócitos totais como de linfócitos T CD4 e CD8. Sendo assim, resolvemos avaliar se o tratamento in vivo com MK801 (0,3 mg/Kg) era também capaz de modular a resposta imune. Para tanto utilizamos o modelo de encefalomielite experimental auto-imune (EAE) em animais C57B1/6 imunizados com MOG $35-55$ (do inglês: Myelin Oligodendrocyte Glycoprotein) emulsificado em CFA (do inglês: Complete Freund Adjuvant). Como pode ser observado na figura 10, o gráfico mostra uma redução significativa na gravidade da doença, quando comparamos o grupo tratado com MK801 ao grupo controle ( $\mathrm{p}<0,01)$. Logo, o bloqueio do NMDAR in vivo repercute numa redução da resposta imune e consequentemente no seu quadro clínico.

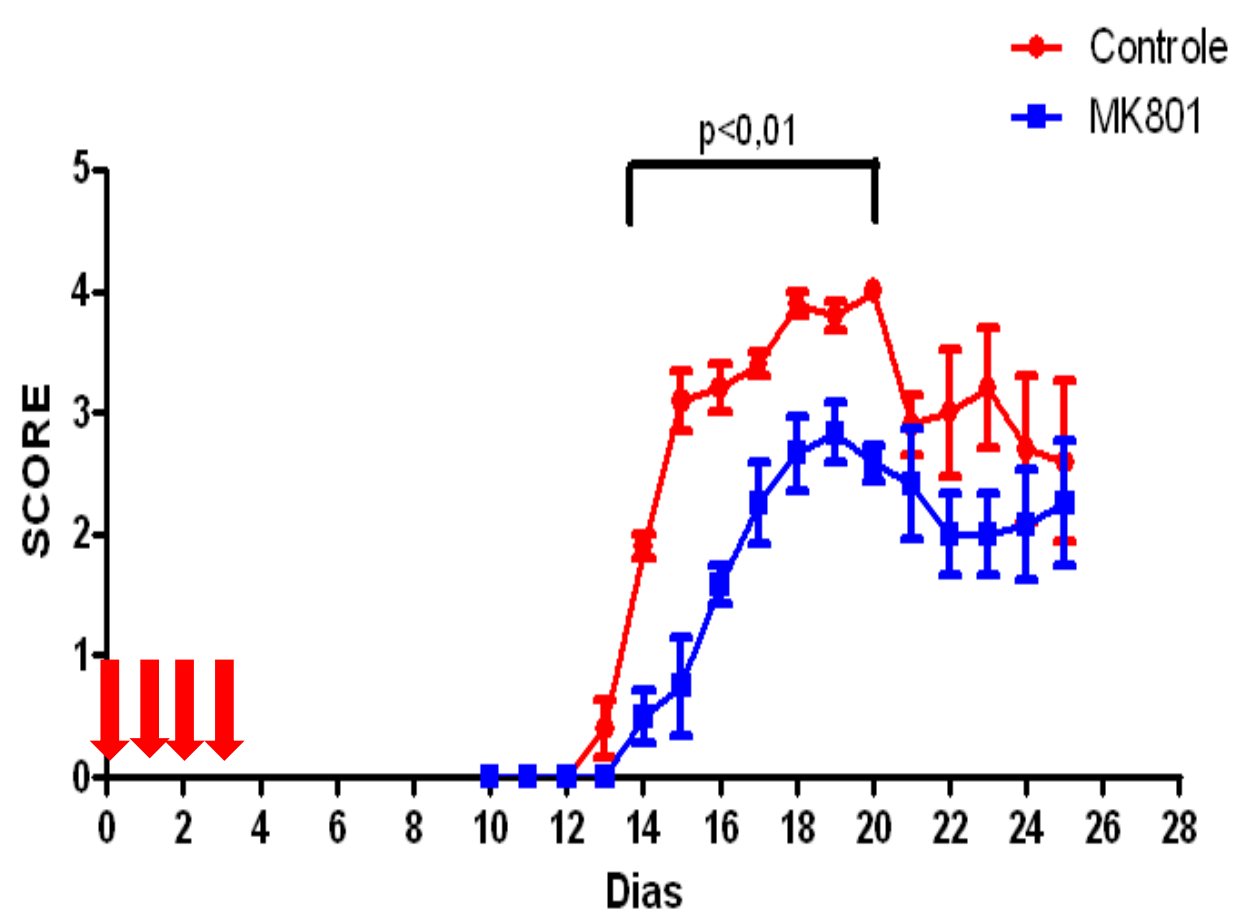

Figura 11: Bloqueio do NDMAR in vivo reduz a gravidade da EAE. Animais imunizados com $\mathrm{MOG}_{35-55}$ foram tratados ou não com 4 doses de $\mathrm{MK} 801(0,3 \mathrm{mg} / \mathrm{Kg})$ como descrito nos materiais e métodos. Os animais foram acompanhados diariamente e o grau de doença distribuído da seguinte forma: 0) sem doença 1) perda do tônus de cauda 2) flacidez ou fraqueza de membros posteriores 3 ) paralisia de membros posteriores 4) fraqueza de membros anteriores 5) paralisia de membros anteriores ou morte. Dados representativos de quatro experimentos independentes. Two-way ANOVA. p<0.01. 


\subsection{Tratamento com MK801 in vivo reduz a fosforilação das MAP quinase ERK 1,2 em esplenócitos totais de animais com EAE}

Como nossos resultados in vitro demonstraram uma redução na fosforilação de ERK 1,2 após tratamento com MK801, sendo que o uso do agonista NMDA apresentou resultado oposto, decidimos também avaliar in vivo se a redução nos scores da EAE se correlacionavam com uma redução na fosforilação de ERK. De fato, como demonstra a figura 12, detectamos por western blot uma redução na fosforilação de ERK 1,2 em esplenócitos totais de animais com EAE previamente tratados com MK801. As células foram obtidas ao dia 7 pós-imunização. Por outro lado, não observamos diferença quando avaliadas células totais dos linfonodos drenantes (Figura 12).
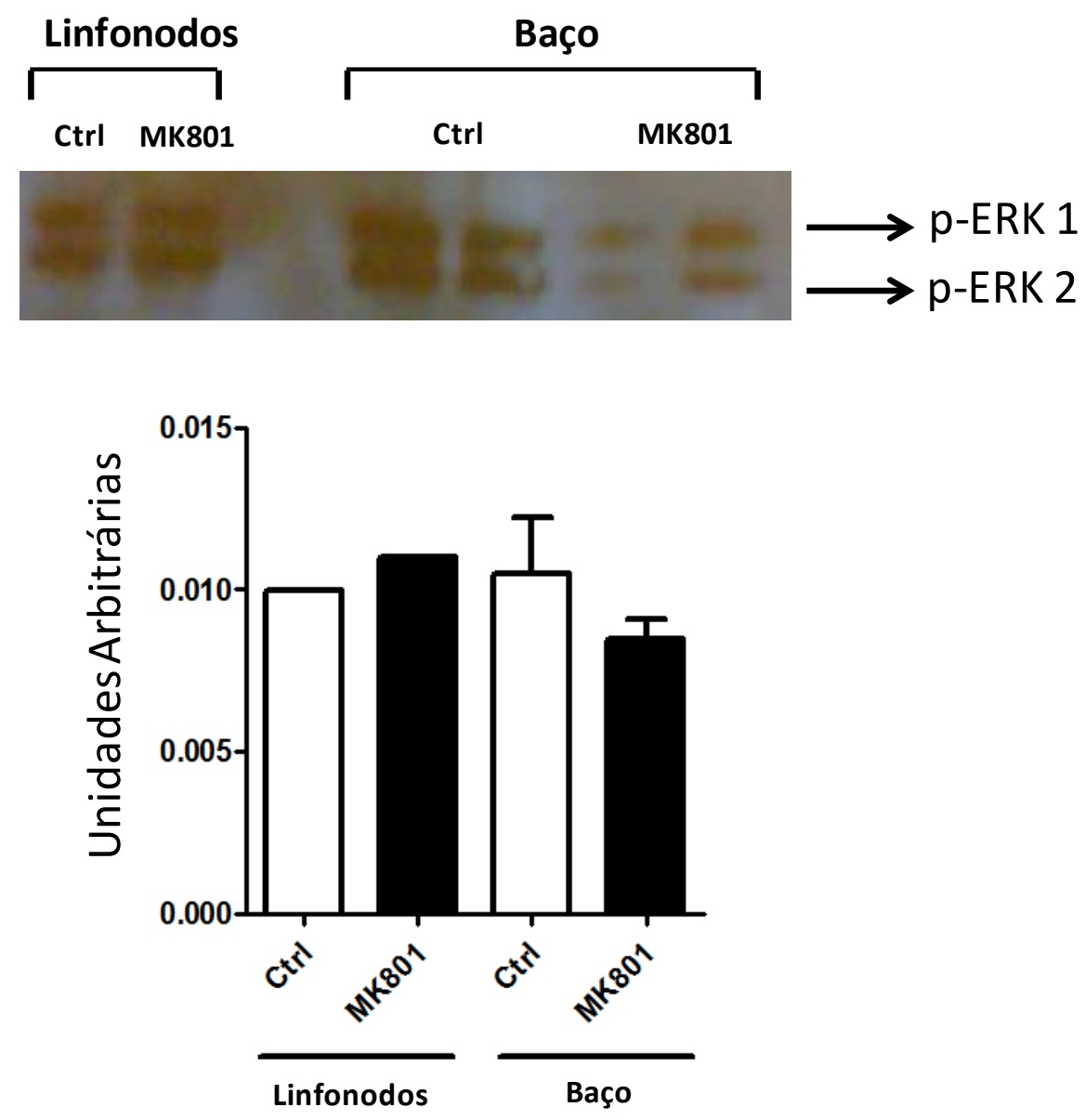

Figura 12: Bloqueio do NMDAR in vivo reduz a fosforilação de MAP Quinases ERK-1 e ERK-2 em esplenócitos totais. Esplenócitos totais foram obtidos de animais imunizados para desenvolvimento de EAE, tratados ou não com MK801 $(0,3 \mathrm{mg} / \mathrm{kG})$, ao dia 7 pós-imunização. As células foram lisadas e submetidas ao protocolo de western blotting para detecção das proteínas ERK-1, ERK-2, e fosfoERK-1 e fosfo-ERK-2. Em A) wesrtern blotting e B) gráfico representativo de leitura densitométrica (Image $\mathbf{J}^{\circledR}$ - NIH). Dado representativa de um único experimento. 


\section{DISCUSSÃO}

Conforme relatado por muitos grupos de pesquisa, células do sistema imune são capazes não somente de expressar uma série de receptores para neurotransmissores [37], como eventualmente secretar os mesmos, dentre eles o glutamato [37,38]. Apesar das evidências de sua presença em células imunes, pouco foi esclarecido a respeito do papel funcional desse receptor nestas células. Através de nossos estudos, obtivemos alguns resultados interessantes acerca da biologia do receptor NMDAR em células do sistema imune. Pudemos observar que, linfócitos T CD4, obtidos ex vivo a partir de camudongos C57B1/6 e de linhagem DO 11.10, expressam o receptor NMDAR, corroborando a literatura. A imunofluorescência de linfócitos T CD4 ex vivo murinos apresentou reação positiva para o anticorpo anti-NR1 na superfície dessas células, indicando a presença de receptor NMDAR nas mesmas. Em células de linhagem DO 11.10, a análise de resultados para expressão de grin1 nos permitiu observar que o padrão de expressão de NMDAR varia de acordo com o estado funcional da célula avaliada, uma vez que células $\mathrm{T}$ naive apresentam expressão diferente de células ativadas com anti-CD3. Tal resultado chama atenção para o fato de que o glutamato pode exercer funções distintas dependendo do estado funcional da célula alvo. Neste contexto, é plausível pensarmos que o glutamato secretado por células dendríticas [38] ou células epiteliais tímicas [37] modula diferencialmente fenômenos moleculares e celulares em células T, dando relevância ao fato de que tanto células naive como células $\mathrm{T}$ ativadas infiltram o SNC durante doenças neuroinflamatórias, local com grande concentração de glutamato.

Com relação ao papel do NMDAR em doenças neuroinflamatórias, estudos documentaram a redução de sinais clínicos em animais frente ao uso de antagonistas para esse receptor $[42,52,53]$ e, a partir desses dados, conferiram ao mesmo o papel pró-inflamatório. Apesar do conhecimento sobre o efeito deletério da ativação do receptor NMDAR sobre essas doenças, pouco se elucidou a respeito dos mecanismos imunomodulatórios envolvidos. Através da avaliação da expressão de fatores anti e pró-inflamatórios para identificar o perfil de citocinas envolvido na ativação do receptor NMDAR, observamos que em células DO11.10 ativadas a expressão de IL-2, IL-10, RORc e SOCS-3 diminui após estímulo do NMDA. Inicialmente formulamos a hipótese de que tal efeito fosse resultado de morte celular provocada por aumento dos níveis de cálcio intracelular. No entanto, ensaios porteriores de proliferação e morte celular mediante a diferentes concentrações de NMDA e MK801, demonstraram que a concentração utilizada em laboratório é adequada e que, portanto, os resultados obtidos por PCR para dose de citocinas não é resultado de morte, mas sim efeito de da ativação ou inibição 
do receptor NMDAR. Quanto à expressão de citocinas, foi observada a redução na expressão da citocina anti-inflamatória IL-10 e da molécula supressora SOCS-3 em células DO 11.10 ativadas por anti-CD3 na presença de NMDA. Para a molécula pró-inflamatórias RORc, que corresponde ao gene codificante para o fator nuclear ROR $\gamma$ t, o receptor NMDAR demonstrou efeito pró-inflamatório em células naive e efeito oposto em células ativadas. Em células naive, o estímulo com NMDA induziu ao aumento de transcritos RORc, e MK801 resultou em redução das mesmas moléculas. Em células ativadas por anti-CD3, o efeito observado foi oposto, uma vez que o estímulo com NMDA provocou redução da expressão de RORc, ao passo que MK801 resultou em aumento. Sendo assim, aparentemente o receptor NMDAR possui efeito próinflamatório sobre linfócitos, uma vez que o estímulo com seu antagonista provoca a redução de marcadores anti-inflamatórios importantes, como IL-10 e SOCS-3. A expressão da molécula pró-inflamatória RORc é influenciada pelo estágio funcional da célula, mas apresenta caráter pró-inflamatório para células naive.

Observamos também que a via de sinalização das MAP quinases ERK-1 e ERK-2, uma via de sinalização bastante relevante e bem caracterizada em linfócitos, está aumentada em células DO11.10 ativadas com NMDA e inibida quando na presença de seu antagonista, MK801. Mais interessante, observamos que células naive apresentam maior intensidade de banda para ERK1, ao passo que para células ativadas isso ocorre com a banda de ERK2. Costumeiramente, é adotado que ERK-1 e ERK-2 possuem funções similares na via de MAP quinases. No entanto, por acreditarmos que diferenças sutis na ativação de vias de sinalização podem refletir em diferenças importantes referente à imunomodulação por NMDA, buscamos na literatura explicação para o dado observado. De fato, Harrington et al (2012) observaram que há uma competição de ERK-1 e ERK-2 por Mek, uma MAP quinase, durante a ativação da via de sinalização das MAP quinases [55]. Segundo os autores, ERK-1 demora mais para ser transportada para o núcleo e mantém sua ativação por menos tempo que ERK-2 e, por isso, o sinal necessário para sua ativação deve ser mais intenso para ativação de ERK-2. Sendo assim, ERK1 necessita de ativação celular para ser acionada, ao passo que ERK2 pode ser mobilizada em células naive. Tais dados vão ao encontro daqueles obtidos por nós. Podemos verificar que em células DO11.10, células naive apresentam banda mais intensa para ERK2 ao passo que células ativadas exibem maior intensidade para a banda de ERK1, em ambos os casos após estímulo com NMDA. Muito pouco se sabe a respeito da do papel biológico para a diferença de ativação entre ERK-1 e ERK-2, mesmo porque há poucos relatos a esse respeito. Não podemos afirmar a influência que a diferença na ativação de ERK tem sobre a modulação imune 
por NMDAR, no entanto é um dado interessante e futuramente, quando as diferenças entre ERK1 e ERK2 forem esclarecidas, teremos mais dados a respeito da modulação por NMDAR.

Afim de avaliar a apoptose por células T CD4 mediante os estímulos com NMDA ou MK, conduzimos ensaios de dose-resposta para viabilidade celular e apoptose em diferentes concentrações de NMDA e MK801. Pudemos observar que o estímulo com o antagonista MK801 sozinho reduz a viabilidade celular e provoca apoptose a uma concentração igual ou superior a $500 \mu \mathrm{M}$. O estímulo com NMDA a diferentes concentrações demonstra que, mesmo a $200 \mu \mathrm{M}$, quantidade superior à que usamos em laboratório, as células T CD4 não apresentam apoptose. No entanto, quando combinamos estímulos de NMDA e MK801 na cultura, verificamos que concentrações crescentes de MK801 resultam em aumento de apoptose. No ensaio de células estimuladas com NMDA e MK801 houve uma discreta redução de células vivas para a quantidade de MK801 utilizada em laboratório, $100 \mu \mathrm{M}$, embora a viabilidade tenha se mantido elevada. A quantidade que utilizamos de MK801, está de acordo com a literatura, uma vez que outras equipes de pesquisa também utilizam o antagonista na mesma concentração, $100 \mu \mathrm{M}$, para estudo da função de NMDAR em células imunes [37,56]. E, da mesma forma, a concentração de NMDA que utilizamos em cultura também está adequada, uma vez que já foi demonstrado por Mashkina et al (2007) que o uso de uma dose de NMDA 50 vezes superior à utilizada por nosso grupo não compromete a viabilidade desse tipo celular [54]. Sendo assim, podemos afirmar que a quantidade de NMDA e MK801 aplicadas em cultura de células em nosso laboratório são corretas e, portanto, apoptose não é o motivo para a redução de citocinas pró-inflamatórias ou da ativação da via de sinalização de MAP quinases. Podemos concluir que os resultados funcionais obtidos com os estímulos de células T CD4 com NMDA e MK801 é resultante da ação do receptor NMDAR sobre as mesmas.

Como mencionado anteriormente, estudos documentaram a redução de sinais clínicos em animais tratados com antagonistas de NMDAR. De fato, em nosso laboratório, o mesmo foi observado. O tratamento de camundongos imunizados com MOG para indução de EAE com o antagonista MK801 mostrou uma redução relevante dos sinais clínicos e grau de doença nesses animais. Para verificar se a inibição da via de MAP quinases também ocorre em animais na presença de MK801, como foi observado in vitro, conduzimos um ensaio para avaliação da ativação dessa via em células ex vivo de animais imunizados com MOG, tratados ou não com MK801. Os resultados demonstram uma marcante redução das bandas de pERK-1 e pERK-2 em células esplênicas de animais tratados com MK801 em relação às de animais não tratados. Maddahi \& Edvinsson demonstraram em 2010 que a inibição da via de MAP quinases por um inibidor da mesma resultou em menor expressão de citocinas pró-inflamatórias importantes em 
doenças neuroinflamatórias (IL-1 $\beta$, IL-6, TNF- $\alpha$ e iNOS) e reduziu os sinais clínicos de isquemia cerebral [57]. Sendo assim, acreditamos que a redução do quadro de doença em animais com EAE pode estar relacionada à inativação da via de MAP quinases frente à inibição do receptor NMDAR por MK801. Em linfonodos, no entanto, não foi observada diferença de fosforilação de ERK entre animais tratados e não-tratados. É possível que a diferença observada esteja relacionada a diferenças funcionais de células imunes de baço e linfonodo para a via de sinzalização de MAP quinases. Foi demonstrado por Baumgarth et al (1997) que existe diferença na a ativação na via de sinalização da MAP quinase ERK-2 de linfócitos ativados de linfonodos mesentéricos e linfonodos de pulmão [58]. Os autores demonstraram que a proliferação celular decorrente de ativação por TCR e sinalização de ERK-2 vista em pulmão não ocorre em linfonodos mesentéricos, onde a proliferação por ativação de TCR ocorre por sinalização independente de ERK. Embora nossos resultados demonstrem a ativação de MAP quinases em linfonodos, ao invés de inibição como demonstrado por Baumgarth et al, é possível que esta via se encontre ativada por haver uma resposta diferenciada da mesma a estímulos neste local. 


\section{CONCLUSÃO}

Em resumo, nossos dados apontam para o glutamato, agindo através de seu receptor ionotrópico NMDAR, como um fator imunomodulador importante da resposta imune, aqui avaliada. A partir dos dados obtidos experimentalmente pelo nosso grupo, podemos concluir que:

- Linfócitos T expressam o receptor NMDAR

- Células naive e ativadas apresentam diferença na expressão de NMDAR

- NMDAR tem a tendência de atuar como pró-inflamatório em células naive

- NMDAR atua sobre a via das MAP quinases em linfócitos T

- Em células naive, NMDA ativa ERK 1 e 2; ao passo que em células ativadas NMDA ativa ERK 2

- A ativação de NMDAR por seu agonista reduz a transcrição gênica e, esta redução não é resultante de morte celular

- Concentrações de MK801 em valores acima de $500 \mu \mathrm{M}$ induz a morte celular em culturas de células in vitro

- O tratamento com MK801 reduz os sinais clínicos de EAE

- $\quad$ O efeito de MK801 sobre a EAE parece ser dependente da via de MAP quinase 


\section{REFERÊNCIAS*}

1. Spector NH. Neuroimmunomodulation takes off. Immunol Today. 1990; 11(11):381-3.

2. Hans S. A syndrome produced by diverse nocuous agents. J Neuropsychiatry Clin Neurosci. 1936; 10(2):230-1

3. Szabo S, Tache Y, Somogyi A. The legacy of Hans Selye and the origins of stress research: a retrospective 75 years after his laNMDArk brief "letter" to the editor of nature. Stress. 2012;15(5):4728.

4. Flammer JR, Rogatsky I. Minireview: Glucocorticoids in autoimmunity: unexpected targets and mechanisms. Mol Endocrinol. 2011;25(7):1075-86.

5. van Westerloo DJ, Choi G, Löwenberg EC, Truijen J, de Vos AF, Endert E, Meijers JC, Zhou L, Pereira MP, Queiroz KC, Diks SH, Levi M, Peppelenbosch MP, van der Poll T. Acute stress elicited by bungee jumping suppresses human innate immunity. Mol Med. 2010;17(3-4):180-8.

6. Basu S, Dasqupta P. Dopamine, a neurotransmitter, influences the immune system. J Neuroimmunol. 2000;102(2):113-24.

7. Pilipović I, Radojević K, Perišić M, Kosec D, Nacka-Aleksić M, Djikić J, Leposavić G. Catecholaminergic signalling through thymic nerve fibres, thymocytes and stromal cells is dependent on both circulating and locally synthesized glucocorticoids. Exp Physiol. 2012; 97(11):1211-23.

8. Rosas-Ballina M, Olofsson P, Ochani M, Valdés-Ferrer SI, Levine YA, Reardon C, Tusche MW, Pavlov VA, Anderson U, Chavan S, Mak TW, Tracey KJ. Acetylcholine-synthesizing T cells relay neural signals in a vagus nerve circuit. Science. 2011;334(6052):98-101.

9. Borovikova LV, Ivanova S, Zhang M, Yang H, Botchkina GI, Watkins LR, Wang H, Abumrad N, Eaton JW, Tracey KJ. Vagus nerve stimulation attenuates the systemic inflammatory response to endotoxin. Nature. 2000;405(6785):458-62.

10. Carson MJ, Thrash J, Walter B. The cellular response in neuroinflammation: The role of leukocytes, microglia and astrocytes in neuronal death and survival. Clin Neurosci Res. 2006;6(5):237-45.

11. MacFarland HF, Martin R. Multiple Scerosis: A complicated picture of autoimmunity. Nat Immunol. 2007;8(9):913-9.

12. Nemethova A, Michel K, Gomez-Pinilla PJ, Boeckxstaens GE, Schemann M. Nicotine Attenuates Activation of Tissue Resident Macrophages in the Mouse Stomach through the $\beta 2$ Nicotinic Acetylcholine Receptor. PLoS One. 2013;8(11).

13. Guereschi MG, Araujo LP, Maricato JT, Takenaka MC, Nascimento VM, Vivanco BC, Reis VO, Keller AC, Brum PC, Basso AS. Beta2-adrenergic receptor signaling in CD4+ Foxp3+ regulatory T cells enhances their suppressive function in a PKA-dependent manner. Eur $\mathrm{J}$ Immunol. 2013;43(4):1001-12.

\footnotetext{
*De acordo com:

International Committee of Medical Journal Editors. [Internet]. Uniform requirements for manuscripts submitted to Biomedical Journal: sample references. [updated 2011 Jul 15]. Available from: http://www.icmje.org
} 
14. Martins LC, Rocha NP, Torres KC, Dos Santos RR, França GS, de Moraes EN, Mukhamedyarov MA, Zefirov AL, Rizvanov AA, Kiyasov AP, Vieira LB, Guimarães MM, Yalvaç ME, Teixeira AL, Bicalho MA, Janka Z, Romano-Silva MA, Palotás A, Reis HJ. Disease-specific expression of the serotonin-receptor 5-HT(2C) in natural killer cells in Alzheimer's dementia. J Neuroimmunol. 2012; 251(1-2):73-9.

15. Cosentino M, Marino F. Adrenergic and Dopaminergic Modulation of Immunity in Multiple Sclerosis: Teaching Old Drugs New Tricks? J Neuroimmune Pharmacol. 2013;8(1):163-79.

16. Cosentino M, Fietta A, Ferrari M, Rasini E, Bombelli R, Carcano E, Saporiti F, Meloni F, Marino F, Lecchini S. Human CD4+CD25+ regulatory T cells selectively express tyrosine hydroxylase and contain endogenous catecholamines subserving an autocrine/paracrine inhibitory functional loop. Blood. 2007;109(2):632-42.

17. Kvaratskhelia E, Maisuradze E, Dabrundashvili NG, Natsvlishvili N, Zhuravliova E, Mikeladze DG. $\mathrm{N}$-methyl-D-aspartate and sigma-ligands change the production of interleukins 8 and 10 in lymphocytes through modulation of the NMDA glutamate receptor. Neuroimmunomodulation. 2009;16(3):201-7.

18. Fallarino F, Volpi C, Fazio F, Notartomaso S, Vacca C, Busceti C, Bicciato S, Battaglia G, Bruno V, Puccetti P, Fioretti MC, Nicoletti F, Grohmann U, Di Marco R. Metabotropic glutamate receptor-4 modulates adaptive immunity and restrains neuroinflammation. Nat Med. 2010;16(8):897-902.

19. Lee M. Neurotransmitters and microglial-mediated neuroinflammation. Curr Protein Pept Sci. 2013;14(1):21-32.

20. Boldyrev AA, Carpenter D, Johnson P. Emerging evidence for a similar role of glutamate receptors in the nervous and immune systems. J Neurochem. 2005;95(4):913-8.

21. Watkins JC, Jane DE. The glutamate story. Br J Pharmacol. 2006;147 Suppl 1:S100-8.

22. Hertz L. Glutamate, a neurotransmitter--and so much more. A synopsis of Wierzba III. Neurochem Int. 2006;48(6-7):416-25.

23. Bai N, Aida T, Yanagisawa M, Katou S, Sakimura K, Mishina M, Tanaka K. NMDA receptor subunits have different roles in NMDA-induced neurotoxicity in the retina. Mol Brain. 2013;6(34).

24. Parpura V, Verkhratsky A. Homeostatic function of astrocytes: $\mathrm{Ca}(2+)$ and $\mathrm{Na}(+)$ signalling. Transl Neurosci. 2012;3(4):334-44.

25. Potapenko ES, Biancardi VC, Zhou Y, Stern JE. Astrocytes modulate a postsynaptic NMDAGABAA-receptor crosstalk in hypothalamic neurosecretory neurons. J Neurosci. 2013;33(2):631-40.

26. Danbolt NC. Glutamate uptake. Prog Neurobiol. 2001;65(1):1-105.

27. Willard SS, Koochekpour S. Glutamate, Glutamate Receptors, and Downstream Signaling Pathways. Int J Biol Sci. 2013;9(9):948-59.

28. Monyer H, Sprengel R, Schoepfer R, Herb A, Higuchi M, Lomeli H, Burnashev N, Sakmann B, Seeburg PH. Heteromeric NMDA receptors: molecular and functional distinction of subtypes. Science. 1992;256(5060):1217-21.

29. Sanchez-Perez A, Llansola M, Cauli O, Felipo V. Modulation of NMDA receptors in the cerebellum. II. Signaling pathways and physiological modulators regulating NMDA receptor function. Cerebellum. 2005;4(3):162-70. 
30. Dravid SM, Erreger K, Yuan H, Nicholson K, Le P, Lyuboslavsky P, Almonte A, Murray E, Mosely C, Barber J, French A, Balster R, Murray TF, Traynelis SF. Subunit-specific mechanisms and proton sensitivity of NMDA receptor channel block. J Physiol. 2007;581(1):107-28.

31. Witt A, Macdonald N, Kirkpatrick P. Memantine hydrochloride. Nat Rev Drug Discov. 2004;3(2): $109-10$.

32. Matute C. Interaction between glutamate signalling and immune attack in damaging oligodendrocytes. Neuron Glia Biol. 2007;3(4):281-5.

33. Huettner JE, Bean BP. Block of N-methyl-D-aspartate-activated current by the anticonvulsant MK801: selective binding to open channels. Proc Natl Acad Sci U S A. 1988;85(4):1307-11.

34. Korde AS, Maragos WF. Identification of an N-methyl-D-aspartate receptor in isolated nervous system mitochondria. J Biol Chem. 2012;287(42):35192-200.

35. Talà A, Monaco C, Nagorska K, Exley RM, Corbett A, Zychlinsky A, Alifano P, Tang CM. Glutamate utilization promotes meningococcal survival in vivo through avoidance of the neutrophil oxidative burst. Mol Microbiol. 2011;81(5):1330-42.

36. Gupta R, Palchaudhuri S, Chattopadhyay D. Glutamate induces neutrophil cell migration by activating class I metabotropic glutamate receptors. Amino Acids. 2013;44(2):757-67.

37. Affaticati P, Mignen O, Jambou F, Potier MC, Klingel-Schmitt I, Degrouard J, Peineau S, Gouadon E, Collingridge GL, Liblau R, Capiod T, Cohen-Kaminsky S. Sustained calcium signalling and caspase3 activation involve NMDA receptors in thymocytes in contact with dendritic cells. Cell Death Differ. 2010;18(1):99-108.

38. Pacheco R, Oliva H, Martinez-Navío JM, Climent N, Ciruela F, Gatell JM, Gallart T, Mallol J, Lluis $\mathrm{C}$, Franco R. Glutamate released by dendritic cells as a novel modulator of T cell activation. J Immunol. 2006;177(10):6695-704.

39. Miglio G, Dianzani C, Fallarini S, Fantozzi R, Lombardi G. Stimulation of N-methyl-D-aspartate receptors modulates Jurkat $\mathrm{T}$ cell growth and adhesion to fibronectin. Biochem Biophys Res Commun. 2007;361(2):404-9.

40. Mashkina AP, Cizkova D, Vanicky I, Boldyrev AA. NMDA receptors are expressed in lymphocytes activated both in vitro and in vivo. Cell Mol Neurobiol. 2010;30(6):901-7.

41. Fallarino F, Volpi C, Fazio F, Notartomaso S, Vacca C, Busceti C, Bicciato S, Battaglia G, Bruno V, Puccetti P, Fioretti MC, Nicoletti F, Grohmann U, Di Marco R. Metabotropic glutamate receptor-4 modulates adaptive immunity and restrains neuroinflammation. Nat Med. 2010;16(8):897-902.

42. Bolton C, Paul C. MK-801 limits neurovascular dysfunction during experimental allergic encephalomyelitis. J Pharmacol Exp Ther. 1997;282(1):397-402.

43. Marsden WN. Synaptic plasticity in depression: molecular, cellular and functional correlates. Prog Neuropsychopharmacol Biol Psychiatry. 2013;43:168-84.

44. Vashishta A, Habas A, Pruunsild P, Zheng JJ, Timmusk T, Hetman M. Nuclear factor of activated T-cells isoform c4 (NFATc4/NFAT3) as a mediator of antiapoptotic transcription in NMDA receptorstimulated cortical neurons. J Neurosci. 2009;29(48):15331-40. 
45. Zheng F, Zhou X, Luo Y, Xiao H, Wayman G, Wang H. Regulation of brain-derived neurotrophic factor exon IV transcription through calcium responsive elements in cortical neurons. PLoS One. $2013 ; 6(12): 28441$.

46. Korhonen R, Moilanen E. MAP Quinase Phosphatase-1 as an Inflammatory Factor and Drug Target. Basic Clin Pharmacol Toxicol. 2013. [A head of print].

47. Xiao L, Hu C, Feng C, Chen Y. Switching of N-methyl-D-aspartate (NMDA) receptor-favorite intracellular signal pathways from ERK-1/2 protein to $\mathrm{p} 38$ mitogen-activated protein quinase leads to developmental changes in NMDA neurotoxicity. J Biol Chem. 2011;(286):23.

48. Chung C. NMDA receptor as a newly identified member of the metabotropic glutamate receptor family: clinical implications for neurodegenerative diseases. Mol Cells. 2013;36(2):99-104.

49. Sarantis K, Antoniou K, Matsokis N, Angelatou F. Exposure to novel environment is characterized by an interaction of D1/NMDA receptors underlined by phosphorylation of the NMDA and AMPA receptor subunits and activation of ERK-1/2 signaling, leading to epigenetic changes and gene expression in rat hippocampus. Neurochem Int. 2012;60(1):55-67.

50. Rossi S, Studer V, Moscatelli A, Motta C, Coghe G, Fenu G, Caillier S, Buttari F, Mori F, Barbieri F, Castelli M, De Chiara V, Monteleone F, Mancino R, Bernardi G, Baranzini SE, Marrosu MG, Oksenberg JR, Centonze D. Opposite roles of NMDA receptors in relapsing and primary progressive multiple sclerosis. PLoS One. 2013;(8):6.

51. Hamasato EK, Ligeiro de Oliveira AP; Lino-dos-Santos-Franco A, Ribeiro A, Ferraz de Paula V, Peron JP, Damazo AS, Tavares-de-Lima W, Palermo-Neto J. Effects of MK-801 and amphetamine treatments on allergic lung inflammatory response in mice. Int Immunopharmacol. 2013;16(4):436-43.

52. Paul C, Bolton C. Modulation of blood-brain barrier dysfunction and neurological deficits during acute experimental allergic encephalomyelitis by the N-methyl-D-aspartate receptor antagonist memantine. J Pharmacol Exp Ther. 2002;302(1):50-7.

53. Kanwar JR. Anti-inflammatory immunotherapy for multiple sclerosis/experimental autoimmune encephalomyelitis (EAE) disease. Curr Med Chem. 2005;12(25):2947-62.

54. Mashkina AP, Tyulina OV, Solovyova TI, Kovalenko EI, Kanevski LM, Johnson P, Boldyrev AA. The excitotoxic effect of NMDA on human lymphocyte immune function. Neurochem Int. 2007;(67):356-60

55. Harrington HA, Komorowski M, Beguerisse-Díaz M, Ratto GM, Stumpf MP. Mathematical modeling reveals the functional implications of the different nuclear shuttling rates of Erk1 and Erk2. Phys Biol. 2012;9(3):036001.

56. Zainullina LF, Yamidanov RS, Vakhitov VA, Vakhitova YV. NMDA receptors as a possible component of store-operated $\mathrm{Ca}^{2+}$ entry in human T-lymphocytes.Biochemistry (Mosc). 2011;76(11):1220-6.

57. Maddahi A, Edvinsson L. Cerebral ischemia induces microvascular pro-inflammatory cytokine expression via the MEK/ERK pathway. J Neuroinflammation. 2010;7:14

58. Baumgarth $\mathrm{N}$, Egerton $\mathrm{M}$, Kelso A. Activated $\mathrm{T}$ cells from draining lymph nodes and an effector site differ in their responses to TCR stimulation. J Immunol. 1997;159(3):1182-91. 